\title{
Seasonal variation of physical, chemical and sensory characteristics of sea bream (Sparus aurata) reared under intensive conditions in Southern Europe
}

\author{
M. Cardinal ${ }^{a,}{ }^{*}$, J. Cornet $^{\mathrm{a}}$, C. Donnay-Moreno ${ }^{\mathrm{a}}$, J.P. Gouygou ${ }^{\mathrm{a}}$, J.P. Bergéa ${ }^{\mathrm{a}}$, E. Rocha ${ }^{\mathrm{b}}$, S. Soares ${ }^{\mathrm{b}}$, \\ C. Escórcio ${ }^{b}$, P. Borges ${ }^{a}$ and L.M.P. Valente ${ }^{b}$ \\ a Ifremer, Laboratoire Science et Technologie de la Biomasse Marine, F-44311 Nantes 03, France \\ ${ }^{\mathrm{b}}$ CIMAR/CIIMAR - Centro Interdisciplinar de Investigação Marinha e Ambiental and ICBAS - Instituto \\ de Ciências Biomédicas de Abel Salazar, Rua dos Bragas, 177, 4050-123 Porto, Portugal \\ *: Corresponding author: M. Cardinal, Tel.: +33 2403740 61; fax: +33 2403740 71, email address : \\ Mireille.Cardinal@ifremer.fr
}

\begin{abstract}
:
This study describes the variability of important quality traits in gilthead sea bream produced under intensive conditions in Southern Europe and purchased in a French market (Nantes). Chemical, sensory and histological characteristics were performed on 18 samples delivered over a year. All fish presented far lower dioxin and DL-PCBs or heavy metals concentrations than the maximum limit level set by EC Regulation, being totally safe for human consumption. Fat content and nutritional values reflected by $n-3$ and $n-6$ polyunsaturated fatty acids (PUFA) levels were parameters with high variability according to the season or the fish farm. Values of $n-3$ PUFA ranged from $0.9 \%$ to $8.6 \%$ and those of $n-6$ PUFA from $9.3 \%$ to $16.6 \%$, corresponding to a respective variation of $n-3 / n-6$ ratio between 0.1 and 0.6. Increased fat levels in flesh lead to a more intense odour, a fatty fish flavour and a whiter appearance of the cooked fillet. Flesh total amino acid composition was rather stable whereas the small differences detected on firmness by the sensory panel were weakly related to histological characteristics. Rearing techniques of the farm seems to modulate the major characteristics of the fish.
\end{abstract}

Keywords: Quality parameters; Sea bream; Sparus aurata; Farmed fish; Chemical composition; Fatty acids; Sensory evaluation; Histological characteristics 


\section{Introduction}

In a general context of increasing worldwide demand for aquatic products combined to the reported decline in wild marine resources, aquaculture is in a position to offer an alternative as a marine protein source. In 2006 , fish farming covered $47 \%$ of the worldwide fish supply (FAO, 2008). As a consequence of this development, questions about quality of farmed products, conditions of rearing and impact of aquaculture on environment become important concerns for all the actors of the sector and for consumer.

Indeed, a lot of studies were undertaken to compare sensorial and nutritional aspects of the main farmed fish species to their wild counterpart (Periago et al., 2005; Grigorakis, 2007; Sveinsdóttir et al., 2009). Farming techniques including environment salinity and temperature, rearing density, feeding procedures or slaughtering conditions were also extensively investigated and correlated to growth and quality criteria (Calabretti, Cateni, Procida, \& Favretto, 2003; Andrew, Holm, \& Huntingford, 2004; Eroldogan, Kumlu, \& Aktas, 2004; Bagni, et al., 2007). All these works allowed developing knowledge on factors involved in fish quality traits and addressed questions related to the increasing awareness for high quality seafood. But despite all effort to establish quality criteria for farmed fish (Kestin \& Warriss, 2001), there is no standard quality for most fish species.

Gilthead sea bream (Sparus aurata) is the major farmed fish species in the Mediterranean region. Its production in 2008 is estimated at 129,000 ton, with Greece and Turkey accounting for almost $90 \%$ of such value (FEAP, 2008). The potential for tailoring flesh composition has been demonstrated in several fish species, including gilthead sea bream (Izquierdo et al., 2005). Moreover, in Atlantic salmon (Salmo salar) and seabass (Dicentrarchus labrax), the firmness of the flesh and colour measurements were positively correlated with the muscle fibre density (Periago et al., 2005; Johnston et al., 2000a). Thus, in order to evaluate flesh quality traits of aquaculture products in Southern Europe it is very important to use a multidisciplinary approach, including sensory properties and nutritional value, which mainly depend on the chemical composition of the fish, without forgetting its sanitary quality. Indeed, if the beneficial role of fish consumption for human health and well being is now well recognized the food safety related to aquaculture is also an important issue and seriously taken into account by the World Health Organization (Anonymous, 1997). In recent years greater attention has been given to food safety issues related to aquaculture. Human exposure to polychlorynated dibenzo-p-dioxines and dibenzofurans (PCDD/F), polychlorinated biphenyles (PCBs) and heavy metal mainly occurs from eating food that contains these chemicals, being fish and other seafood important sources of those contaminants. To prevent health risk from PCDD/Fs, PCB's and some toxic heavy metals the European commission established maximum levels in the different food items, including fish (Commission Regulation (EC) $N^{\circ} 1881 / 2006$ modified by $N^{\circ}$ 629/2008). There is extensive literature documenting the bioaccumulation of those contaminants in a great variety of fish species purchased in several fish markets across Europe ( Bordajandi et al., 2004; Domingo \& Bocio, 2007), but relatively little data is available on aquaculture products (Bell, McGhee, Dick, \& Tocher, 2005; Pinto et al., 2008).

The purpose of the present study was to describe through different and complementary approaches the seasonal variation of quality characteristics for commercial gilthead sea bream produced in different Southern European fish farms under intensive conditions and available to consumers. Quality criteria took into account sanitary, nutritional, sensory and yields aspects. These criteria were evaluated by physical measurements (histology, colour and yield), chemical analyses (water, lipid, protein and ash content, fatty acid and amino acid profile, heavy metals and PCDD/Fs and PCBs levels) and sensory evaluation in order to get a global overview of the range of variation for sea bream quality parameters along a period of one year. To assess this information, sea bream was collected in hypermarkets and wholesalers, in the city of Nantes (France), at three different seasons. This study aimed to know if sea bream from intensive production system delivered to consumer, has constant 
characteristics, by identifying the range of variation for selected quality criteria that are of main interest for the consumer.

\section{Material and methods}

\subsection{Fish sampling}

Sea bream of standard commercial size (300-400 g) were purchased on local market at Nantes (France) in wholesalers and supermarkets at three different periods: June 2007 (Period 1), October 2007 (Period 2) and March 2008 (Period 3). These dates were chosen to clearly reflect the influence of seasonal temperature fluctuations experienced by the fish on its growth and hence flesh quality. At each period, six intensive fish farms were selected according to their availability on the French market and in order to reflect the quality characteristics that a consumer could expect. Hence, two farms were systematically sampled over the three periods (farms A and B), two other farms were sampled in Period 1 and 2 (E1 and E2) or in Period 1 and 3 (F1 and F3), all the others varied according to the local supermarkets supply (farms C, D and G to O). Overall a total of eighteen samples (6 farms over 3 periods) were analysed during one year according to the organisation scheme presented on figure 1. Thirty fish, from each farm, were purchased in supermarkets and wholesalers at each period, and countries of production were Greece, France and Spain. Labelling allowed knowing the farming location and the rearing structure (cage or pond) as well as the date of slaughtering but no other information on farming conditions was available. All the samples were qualified as intensive production by the supplier. Fish from one of the French farms (A) were reared in a land pond; all the other samples came from sea cages. The thirty fish purchased from each fish farm were analysed immediately after their purchase. The yield was determined on twenty fish at each step of the filleting process. Composition analysis was realised on three grinded whole fish as well as on the flesh of three other trimmed fish. Colour of the fillets was measured on five fish and 12 fish were necessary for sensory evaluation. Measurements of histology were performed on slices from three different fish to evaluate the muscle structure.

\subsection{Body traits evaluation}

At each sampling period, thirty fish from each farm were weighed and measured and the condition factor was determined (weight $/$ length $^{3}$ ). Twenty fish were gutted, filleted and trimmed always by the two same persons. Trimming procedure allowed peritoneum, bones, visible dorsal fat depot and visible belly flap fat to be eliminated. A fillet with skin was obtained. Loss were calculated at each step and expressed as a percentage of total weight of whole fish, for viscera, head and bones, trimmed part (peritoneal deposit and dorsal fat deposit). The edible fraction, including skin of the fish was calculated in the same way. In the present study results for this fraction will be slightly overestimated in comparison with other works.

\subsection{Proximate analyses, fatty acid and amino acid profile}

For each batch of fish received from each farm during the study, three grinded whole fish were pooled. The flesh of trimmed fillets, the edible part of the fillet i.e. without perivisceral fat deposit and subcutaneous adipose tissue, from three other fish was also grinded and pooled. Both whole body and flesh samples were freeze dried and all samples were analysed in duplicate. Dry matter content was determined after oven drying $10 \mathrm{~g}$ of sample at $103^{\circ} \mathrm{C}$ for one night. Ash content was carried out by ignition of $1 \mathrm{~g}$ of sample at $600{ }^{\circ} \mathrm{C}$ for $24 \mathrm{~h}$ (AOAC, 2005). Lipids were extracted according to the Folch procedure (Folch, Lees \& Sloane- 
Stanley, 1957). Total lipid content was determined gravimetrically after solvent extraction and evaporation. The total nitrogen content was determined on $200 \mathrm{mg}$ of sample using a micro system of Kjeldahl method (AOAC, 2005). Crude protein was estimated by multiplying the total nitrogen content $(\% \mathrm{~N})$ by the factor 6.25 . Fatty acid profile was obtained by separation and quantification of the fatty acids methyl esters using a capillary column with high polarity (BPX 70, 60m long, $0.25 \mathrm{~mm}$ internal diameter, $0.25 \mu \mathrm{m}$ film thickness, stationary phase cyanopropyl siloxane) using a gas chromatograph Perkin Elmer Autosystem equipped with a FID detector $\left(300{ }^{\circ} \mathrm{C}\right)$. Fatty acids were identified by comparison to internal standard

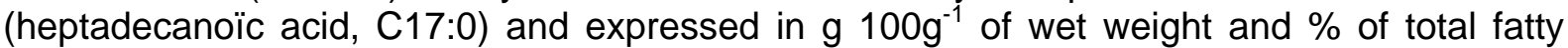
acids.

The EZ:faast ${ }^{\mathrm{TM}}$ procedure (Phenomenex, USA) has been used for the amino acid analysis of protein. An acid hydrolysis with $6 \mathrm{~N} \mathrm{HCl}$ was carried out on $10 \mathrm{mg}$ of freeze-dried sample. The EZ:faast amino acid analysis procedure consists of a solid phase extraction step followed by derivatization and liquid/liquid extraction with the EZ faast kit. Derivatized samples were quickly analysed by gas chromatography on Zebron ZB-AAA GC column $(10 \mathrm{~m} \times 0.25 \mathrm{~mm})$ of chromatograph Perkin Elmer Autosystem XL with FID detection $\left(320^{\circ} \mathrm{C}\right)$. Helium was the carrier gas used at a constant flow rate of $1.5 \mathrm{~mL} / \mathrm{min}$. The amino acids were expressed in

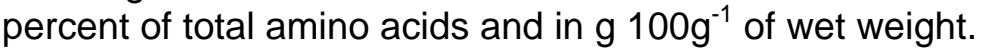

\subsection{Contaminants}

Contaminant analyses were performed on freeze dried samples obtained from the flesh of seven fish (all the edible part of four whole fish plus the remaining flesh of the three fish used for histology assessment).

\subsubsection{Analysis of dioxins and dioxin-like PCBs}

All analytical procedures for polychlorinated dibenzo-p-dioxines (PCDDs), polychlorinated dibenzofurans (PCDFs) and dioxin-like polychlorinated biphenils (DL-PCB) analysis in the muscle were subcontracted to an external accredited laboratory according to ISO/IEC 17025 (Silliker-Eurofins). The most toxic individual congeners of PCDDs (2,3,7,8-TetraCDD, 1,2,3,7,8-PentaCDD, 1,2,3,4,7,8-HexaCDD, 1,2,3,6,7,8-HexaCDD, 1,2,3,7,8,9-HexaCDD, 1,2,3,4,6,7,8-HeptaCDD, OctaCDD), PCDFs (2,3,7,8-TetraCDF, 1,2,3,7,8-PentaCDF, 2,3,4,7,8-PentaCDF, 1,2,3,4,7,8-HexaCDF, 1,2,3,6,7,8-HexaCDF, 1,2,3,7,8,9-HexaCDF, 2,3,4,6,7,8-HexaCDF, 1,2,3,4,6,7,8-HeptaCDF, 1,2,3,4,7,8,9-HeptaCDF, OctaCDF) and DLPCBs (PCB 77, PCB 81, PCB 126, РCB 169, PCB 105, РCB 114, РCB 118, РCB 123, PCB 156, PCB 157, PCB 167, PCB 189) were analysed and their sum was expressed in World Health Organization (WHO) toxic equivalents (TEQ) using their assigned toxic equivalency factors (pg WHO-PCDD/F-PCB-TEQ/g wet weight). Upperbound TEQ values were calculated assuming that non-detected individual congener concentrations were equal to their corresponding limits of detection.

\subsubsection{Analysis of heavy metals}

Total metal contents were determined in muscle by atomic absorption spectrophotometry (SpectrAA 220FS, Varian, with background correction through a deuterium lamp) with flame or electrothermal atomization (GTA 110 unit) according to Reis \& Almeida (2008). Pyrolysis and atomization temperatures were optimized to obtain the maximum sensitivity and precision with the minimum of interferences. Accuracy of the analytical procedure was checked by analysing Dorm-2, Dogfish Muscle, certified for the concentrations of arsenic (As), cadmium (Cd), mercury ( $\mathrm{Hg})$, nickel $(\mathrm{Ni})$ and lead $(\mathrm{Pb})$; Dorm-2 was obtained from the National Research Council of Canada. Aqueous matched standards were used for external calibrations. Average values were calculated assuming that non-detected metal concentrations were equal to their corresponding limits of detection. 


\subsection{Histological characteristics}

Fish were weighed individually to the nearest $\pm 0.1 \mathrm{~g}$ and measured (fork length) to the nearest $\pm 0.1 \mathrm{~cm}$. After that, the fins were cut, the scales gently removed and one crosssectional body slab (2-3 mm thick) was removed from the region immediately before the first dorsal fin. The samples (3 fish per fish farm) were fixed in Bouin's (Panreac, Barcelona, Spain) fluid for 72 hours, with sporadic shaking. After fixation, and under a stereomicroscope, each slab was longitudinally cut in two (right and left) equal-sized (mirror) halves. The pieces were then routinely dehydrated in a graded ethanol series, cleared in xylol, and finally embedded in paraffin. Three $10 \mu \mathrm{m}$-thick section were cut per block, and then stained with haematoxylin-eosin before being coversliped for morphometric analysis. Morphometric measurements were made on dorsal muscle transversal sections using an interactive image analysis system (Olympus Cell`Family), captured by CCD-video camera (ColorView Soft Imaging System, Olympus) and a light microscope (BX51, Olympus, Japan). Fish dorsal cross-sectional area (A), in $\mathrm{mm}^{2}$, was computed by the software after circumscribing half of the physical limits of the whole dorsal section. Such delimitation was made using the mouse and under a $1.25 \times$ objective lens. An estimate of the total dorsal area [A (dorsal area)] was obtained by doubling the computed value. The relative area occupied by a particular tissue component $\left[A_{A}\right.$ (tissue area)], either dorsal white or adipose tissue, was delimited by circumscribing the physical limits of interest in half of the section, using the mouse and under $1.25 \times$ objective lens. An estimate of the total dorsal white muscle area or adipose area was made by doubling the computed value. The relative numbers of white muscle fibres per unit area $\left(\mu m^{2}\right)$, within the respective muscle zones [ $N_{A}$ (fibres)], were estimated as follows: $N_{A}$ (fibres) $=\Sigma N$ (fibres) $\div \Sigma$ [a (sampled field)] where $\Sigma N$ (fibres) is the total number of fibres counted over three sampled fields in a section, selected according to Rowlerson, Mascarello, Radaelli, \& Veggetti (1995), and "a" is the total area of the fibre counting fields. The total number of white muscle fibres per dorsal cross section $(\mathrm{N})$ was estimated as follows: $N$ (fibres) $=N_{A}$ (muscle fibres) $\times A_{A}$ (muscle) where $N_{A}$ is the number of white muscle fibres per unit area $\left(\mu \mathrm{m}^{2}\right)$ and $A_{A}$ the relative area occupied by a particular tissue component. Finally, the mean individual muscle fibre area [ā (fibre)] was estimated by circumscribing the physical limits of the fibre section. The corresponding diameter was computed as follows: D (muscle fibre) $=2 \bar{a}^{0.5} \pi^{-0.5}$. All measurements of white fibres were made with the $20 \mathrm{x}$ objectives over three sampled fields within a section, selected according to Rowlerson et al. (1995).

\subsection{Colour measurement}

Colour was determined from five fillets, using a Spectrocolorimeter CM-500i with a D65 light source and a $10^{\circ}$ observer (Konica Minolta sensing Europe, France) calibrated to black and white standards. The tristimulus $L^{*}, a^{*}, b^{*}$ measurement mode $(\mathrm{CIE}, 1976)$ was used as this relates to human eye response to colour. The $L^{*}$ variable represents lightness $\left(L^{*}=0\right.$ for black, $L^{*}=100$ for white), while the $a^{*}$ scale represents the red/green dimension, with positive values for red and negative ones for green. The $b^{\star}$ scale represents the yellow/blue dimension, with positive values for yellow and negative ones for blue (Dordet, 1990). Colour was measured on five different spots on dorsal part of each fillet, avoiding the lateral line, in raw and cooked presentation. Results are shown as the mean of these measurements.

\subsection{Sensory evaluation}

Twenty one panellists, belonging to the IFREMER staff and selected for their experience on fish characteristics evaluation, carried out conventional profiling (ISO, 2003) to evaluate the sensory properties of sea bream. Descriptors were selected thanks to previous sessions of 
description and training on different fish species (sea bream, sole and pike perch). These sessions allowed to find a consensus around sensory description of each species and to check the panellists' understanding of the descriptors. Sensory criteria chosen for sea bream cooked fillet related to the appearance, odour, flavour and texture were, for odour: global intensity, fat fish, marine-iodin like, boiled milk, earthy, sour milk; for appearance, colour homogeneity, white colour, coagulated proteins, brown spots, black stria, fat droplets in gravy; for texture, firmness, density of the flesh, moisture, fibrous texture, sticky texture, chewiness, fat film and for flavour, global intensity, fat fish, potato, earthy, salty, bitter, metallic. At each period, six batch of sea bream were evaluated in two sessions. Panellist received three samples per session, assigned 3-digit numbers and constituted of a central part of a fillet without skin, cooked in a glass bowl covered with a cap. After cooking in a microwave oven (Samsung) during $1.8 \mathrm{~min}$ at $600 \mathrm{~W}$, the three fillets were randomised and served simultaneously. Panellists were asked to consume the dorsal part of the fillet. Sessions were performed in individual partitioned booths equipped with a computerised system (Fizz system, Biosystèmes, Dijon, France). These conditions were conducive to concentration and avoided communication between assessors and disturbance by external factors (ISO, 1988). Panellists rated the sensory attributes on a continuous scale presented on a computer screen, ranging from low (0) to high intensity (10).

\subsection{Statistical analysis}

Statistical analyses followed methods outlined by Zar (1999). The mean, standard deviation, analysis of variance, LSD multiple range test and correlations among parameters were performed using Statgraphics Plus Centurion XV.I software (Sigma Plus, Paris, France). The significant statistical level was set at $p<0.05$. Multivariate data processing was performed with Uniwin 6.1 software (Sigma Plus).

\section{Results}

\subsection{Body morphological traits and whole body composition}

The body traits are reported in Table 1 . Whole fish weights from periods 1 and 3 differed significantly; the highest mean $(418.9 \mathrm{~g})$ registered in March 2008 is due to the delivery of two samples slightly above the targeted commercial size (300-400 g). The standard deviation of whole body weight values reflects this variation, both in period 2 and 3 where one of the received samples displayed a 400-600 g size range. Condition factor is significantly lower in March compared to October and can be a consequence of a low fat deposition after the winter period in relation with the feeding intensity as mentioned in the review of Grigorakis (2007). Regarding commercials traits, although a significant difference is noticed on trimming losses, $16.5 \%$ vs $15.1 \%$, for period 1 and 3, respectively, no significant differences resulted on the edible part. However, whatever the season, for this size range of fish, the edible fraction obtained on sea bream remained stable around $41.5 \%$.

Final whole body composition of sea bream reared in intensive systems is presented in Table 1. The results represent arithmetic means of fish from six different fish farms. There was an important range of variation for all nutrients resulting in significant differences among seasons. The dry matter percentage varied between 35 and $38 \%$, whereas fat content ranged between 14 and $18 \%$. In March, whole body composition of fish displayed minimal values for all parameters. October is the period where fish have the highest fat content and the difference with values obtained in March is significant. It is also worthwhile referring that both dry matter and lipid content varied significantly $(p<0.05)$ within each season (data not presented). Whole body fat content was positively correlated with the visceral fraction eliminated during the gutting step $(P<0.05)$. 


\subsection{Chemical analyses on fillet}

\subsubsection{Analyses of contaminants}

A summary of PCDD/PCDF, dioxin-like PCBs, the most toxic heavy metals and the metalloid arsenic have been determined in muscle (Table 2). WHO-TEC values for each group are also shown. The results represent arithmetic means of the muscle samples collected in six different fish farms at two periods.

PCDF analytical contributions are greater than those of PCDD and both are lower than those of PCBs. The 2,3,7,8- tetraCDF was the predominant congener in all samples $(0.26 \mathrm{pg} / \mathrm{g} \mathrm{ww})$ followed by the 2,3,4,7,8-pentaCDF. Moreover, the most toxic congener, the 2,3,7,8tetraCDD was detected in all samples at very low levels $(0.01 \pm 0.01 \mathrm{pg} / \mathrm{g}$ wet weight). Among PCBs, the most toxic "dioxine-like" congeners PCB 126 and 169 showed the lowest levels, whereas PCB 118 and 105 were the most concentrated (484.9 and $152.1 \mathrm{pg} / \mathrm{g} \mathrm{ww}$, respectively). Moreover, PCB 126 was the only one varying significantly between seasons $(P<0.05)$ and displayed maximal values by the end of the spring. The WHO-TEQ for both PCBs $(0.4 \pm 0.1 \mathrm{pg} / \mathrm{g}$ wet weight) and PCDD/F $(0.1 \pm 0.01 \mathrm{pg} / \mathrm{g}$ wet weight) did not vary much with the season or fishing grounds (data not presented) and were very low.

The most toxic heavy metals and the metalloid arsenic determined in muscle are shown in Table 2; no seasonal variation could be depicted for $\mathrm{As}, \mathrm{Cd}$ and $\mathrm{Hg}$, but $\mathrm{Ni}$ displayed maximal values in October whereas $\mathrm{Pb}$ was more concentrated in June. The concentrations obtained in this study for the different samples showed total arsenic (As) as the element presenting the highest levels, followed by nickel $(\mathrm{Ni})$, mercury $(\mathrm{Hg})$, lead $(\mathrm{Pb})$ and finally cadmium (Cd).

\subsubsection{Protein content and total amino acid profile}

The flesh protein content of sea bream reared in intensive conditions varied from $18.5 \%$ to $20.6 \%$, according to the period (Table 3). Within each period, the standard deviation measured was very low. Total amino acids composition of the muscle samples collected in six different fish farms at the three periods is presented in Table 3. Except tryptophane, not preserved during the acid hydrolysis procedure and arginine, not eluted by the column, sixteen amino acids have been detected. Glutamic acid and aspartic acid levels were the highest, with a mean of $15.0 \%$ and $12.3 \%$, respectively. This repartition remains stable whatever the period. Among essential amino acids, leucine, isoleucine and valine presented the highest percentage of total amino acids. The sum of essential amino acids in samples ranged from 6.3 to $8.7 \mathrm{~g} 100 \mathrm{~g}^{-1}$ of sea bream flesh with significant differences between October and the two other periods. The significant differences observed between periods on some amino acids did not affect the general distribution of amino acids within a period; hence the amino acids profile remained relatively unchanged.

\subsubsection{Fat content and fatty acid profile}

Results on flesh composition from a pool of three fish from each farm indicate a relatively high fat content in reared sea bream with an overall mean of $9.9 \%( \pm 2.7)$ for the eighteen samples (Table 4). As for whole fish, the difference in muscle lipid content was significant between periods; the highest mean for fat level was observed in October (11.9\%). Within each period, the standard deviation was rather large and varied between 2.1 and 2.8. In fact, muscle lipids content varied from $6.1 \%$ to a maximal value of $14.8 \%$, according to the season and the farm location.

Table 4 shows the profile of fatty acids in sea bream flesh, over this study and for each period. Analytical results showed high levels of saturated $(40.7 \%)$ and monounsaturated 
(40.9\%) fatty acid groups and a relatively low level (18.3 \%) of polyunsaturated fatty acids (PUFA) over the year. Moreover, the n-3 polyunsaturated fatty acids fraction was generally very low, especially in June where the level decreased to $0.9 \%$. The maximum value $8.6 \%$ was observed in March, just after the winter season. Palmitic acid (C16:0), oleic acid (C18:1n-9) and linoleic acid (C18:2n-6) were the main constituents of the muscle fatty acid profile. The large variation of values within each period did not allow detecting any significant differences between periods for these fatty acids. On the contrary, levels of eicosapentaenoic $(C 20: 5 n-3)$ and docosahexaenoic (C22:6n-3) acids were very low, with a global average of $1.9 \%$ and $1.8 \%$, respectively, and significant differences were noticed between periods.

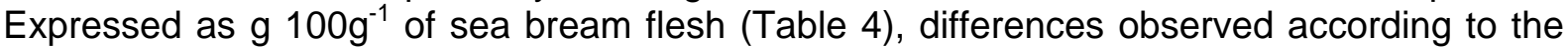
season are confirmed but these differences are sometimes fewer. Sea bream analysed in March still presented higher levels of n-3 PUFA, significantly different from samples analysed in June but levels are quite similar to those noticed in October. Results confirmed also the higher levels of linoleic acid in June

\subsection{Physical analyses}

\subsubsection{Muscle structure}

Muscle cellularity results are presented in Table 5. The results represent arithmetic means of the samples collected in six different fish farms. The total mean cross-sectional area occupied by the subcutaneous adipose tissue varied significantly $(P<0.05)$ among seasons. Fish sampled in October displayed significantly higher values than fish sampled either in June or March. Moreover, there was a significant variation $(p<0.05)$ within seasons concerning this parameter (data not presented). There were significant seasonal variations concerning muscle dorsal cross-sectional area and the total number of white fibres in the dorsal muscle $(\mathrm{P}<0.05)$. In October, fish showed the highest mean muscle area value (white: $\left.445.5 \pm 51.7 \mathrm{~mm}^{2}\right)$ and the highest number of muscle fibres (161600 \pm 23300$)$. Moreover, alike subcutaneous adipose tissue, there was a significant variation $(p<0.05)$ within seasons concerning white muscle total dorsal cross-sectional area and white fibre number (data not presented).

The fibre diameter and fibre density for white muscle did not vary significantly with the season. Moreover, samples analysed in March varied significantly among fish farms concerning these two parameters $(P<0.05$, data not shown).

\subsubsection{Colour}

The measured colour of sea bream samples evaluated in this study (Table 5) did not reflect a great variability. Lightness values of the raw samples ranged from 41.2 to 43.1 and the values of red and yellow colour, $a^{*}$ and $b^{*}$, ranged respectively from -1.5 to -0.5 and from 0.4 to -0.04 , according to the period. A significant difference was only observed on the $a^{*}$ parameter with samples collected in March presenting a slightly less red colour. After cooking, those samples had a significantly lower lightness and a tendency to a higher $b^{*}$ value (yellow hue). The general appearance of cooked fillets is a white colour with a more or less marked yellow hue.

\subsection{Sensory characteristics}

A two way analysis of variance was carried out on each sensory score attributed by each panellist to the 18 samples of sea bream cooked fillets. Two independent factors were tested, panellists and products corresponding to fish farms. Significant differences between 
samples appeared on fifteen criteria $(p<0.10)$ out of twenty six. $F$ ratio of the Fisher test for product effect was chosen as indicator to classify sensory descriptors according to their discriminative power. The descriptors ranked from the highest to the lowest $F$ value were the following: white appearance of the flesh, fatty fish flavour, droplets in gravy, black spot on the flesh, homogeneity of the colour, global intensity of the flavour, fat film in mouth, salty taste, black stria on flesh, fat fish odour, global intensity of odour, coagulated protein on flesh surface, moisture of the flesh, firmness, and marine odour.

The fifteen sensory descriptors with the highest discriminative power were selected in order to highlight the main characteristics variations of the different commercial sea bream. A principal component analysis (PCA) with standardization was performed on panel mean scores obtained for each descriptor and each sample. Samples were identified by a code referring to the farm and to the period. The simultaneous representation of sensory variables and samples gave a global view of the main sensory characteristics of each sample (Figure 2). Moreover this figure evidenced the criteria with the highest variations between samples and those which were correlated. The first axis which accounts for $41.4 \%$ of the total information was mainly created by descriptors of appearance white colour and homogeneity of the colour, descriptors of flavour as global intensity and fat flavour, descriptors of texture as perception of fatty film in mouth and also by some criteria of odours, especially global intensity and fat fish. On the right part of the figure, we found samples with high scores for these descriptors and at the opposite on the left part, samples with low scores for these descriptors and high for one criteria of appearance, brown spots on flesh surface. The second axis represented $15.9 \%$ of the total variability and mainly consisted of criteria of texture, firmness and moisture of the flesh as well as one criterion of appearance, black stria on the flesh and one descriptor of odour, marine odour. The first axis illustrates the main sources of sensory variability among samples. On a 10 points scale of scoring, criteria as white colour, fat flavour and fat droplets had a range of variation of 2.3, 3.2 and 2.8 points respectively whereas firmness and marine odour (axis 2) varied only of 1.1 and 1.5 points, respectively (data not shown). The right part of Figure 2 presents the samples with the highest intensity for global odour and flavour with mainly fatty fish characteristics. A global decreasing intensity appeared for these descriptors toward the left part of the figure. Moreover samples from period 3 were all gathered together in the left part of the figure that could illustrate a general seasonal effect. Indeed, period of March had been previously noticed to have the lower mean of fat content and could therefore explain these characteristics. It is interesting to note also the location of samples $A, B$, and $E$ analysed at two or three periods. The three samples from the farm A presented close characteristics and seemed to have little sensory differences according to the period. Compared to samples $A$, sea breams from the farm $E$ developed a more fatty fish, in odour and flavour, presented a fat film in mouth and had a more white colour; these characteristics were persistent along the two period of analysis. Samples from farm B kept roughly the same characteristics over the three periods but in a lesser extent in comparison with farm $A$, because firmness of the sample B_3 is slightly higher. At least, samples from the farm $\mathrm{N}$ analysed at the same period but on different fish size (300-400 g and 400-600 g) showed also close characteristics. The second axis discriminated, in a lesser extent, samples according to the firmness and moisture; slightly higher firmness on the top of the figure and higher moisture on the bottom.

\subsection{Relation between sensory characteristics and instrumental measurements}

The relationships between chemical, physical and histological measurements and main sensory properties, identified as the most important in the characterization of the products have been assessed by calculating correlation between principal components of the PCA on sensory descriptors and each instrumental parameters (Figure 3). The highest correlations were identified between muscle dry matter and lipid content and the intensity of global flavour, the fat flavour, the fat film perception in mouth and also the presence of fat droplets in the bowl after cooking. All these sensory descriptors increased with muscle lipid content 
and in a lesser extent with the level of polyunsaturated fatty acids n-6. It can also be noticed a good correlation between the lightness of the flesh after cooking expressed by $L^{*}$ value, the lipid content of the muscle and the panel perception for white colour and colour homogeneity. Our overall results do not show clear correlation between sensory characteristics of texture and histological parameters. Nevertheless, in March, fibre density varied significantly among fishing grounds and was positively correlated with the attributes chewiness (0.943) and density (0.886). In addition, flesh firmness was positively correlated with the total number of white fibres (0.885) and negatively correlated with fibre diameter (-0.943)

\section{Discussion}

Irrespective to the different rearing conditions as feeding regime, feed composition and starvation period, specific in each farm, significant differences were observed on body morphological traits and whole body composition (Table 1) according to the period of analysis. Whole fish weights from periods 1 and 3 differed significantly, thought no significant differences resulted on the edible part. The observed difference on trimming loss (16.5\% vs $15.1 \%$, for period 1 and 3, respectively) could be a direct effect of fish size but could also be due to the feeding rate or dietary fat level, as previously observed by Hillestad, Johnsen, Austreng, \& Åsgård. (1998) on Atlantic salmon. However, whatever the season, for this size range of fish, the edible fraction obtained on sea bream remained stable around $41.5 \%$. It can be suggested that the lower trimming losses observed for fish in period 3 are balanced by the relatively higher head-bones fraction. This mean value of $41.5 \%$ of the total body weight for the skeletal muscle is consistent with the range of variation, from 34.3 to $48 \%$, previously reported in a review of Grigorakis (2007) for gilthead sea bream. This wide distribution of values observed in literature could be a consequence of many factors as feeding history (energy of the diets, feeding rates) but probably mainly explained by a difference in filleting techniques among the different studies. The comparison of results is therefore difficult. However, our study does not show great variation on the edible part of commercial sea bream among seasons or sampling locations. Nevertheless, there was an important range of variation in final whole body composition of sea bream resulting in significant differences among seasons. In March, whole body composition of fish displayed minimal values for all parameters, except ash content, whereas in October fish have the highest fat content. The primary determinants of proximate composition in growing fish are life cycle stage, fish size and energy intake, but other environmental factors can also have an important role (Shearer, 1994). In March, whole body protein and lipid displayed minimal values probably due to reduced feeding related to the low water temperatures during winter, and to the process of gonadal maturation. These findings are in agreement with results from literature on seasonal impact, which indicate low fat depots after winter and increased fat depots at the end of the summer and beginning of autumn, which correspond to the middle and end of the high intensity feeding in gilthead sea bream (Grigorakis, 2007). In the present work, it is also worthwhile noticing the high variation registered among rearing locations, within each season, which were probably due to different feeding regimes and different water temperatures between the different countries. Whole body fat content was positively correlated with the visceral fraction $(p<0.05)$, eliminated during the gutting step, suggesting a preferential perivisceral fat deposition in gilthead sea bream. Moreover, overall high flesh lipid content observed in this study corresponds well to data previously reported in literature for farmed gilthead sea bream and confirms the difference found between intensively cultured fish and its wild counterpart (Grigorakis, 2007).

Regarding the sanitary quality of the fish flesh, the predominance of congeners $2,3,7,8$ tetraCDF and 2,3,4,7,8-pentaCDF in all samples is consistent with the general toxicity pattern reported for fish (Domingo et al., 2007, Papadopoulos, Vassiliadou, Costopoulou, Papanicolaou, \& Leondiadis, 2004). The two congeners 118 and 105 have already been reported as the highest levels of $\mathrm{PCB}$ having an assigned TEF-value (Toxic Equivalent 
Factor) (Baeyens, et al. 2007; Llobet, Martí-Cid, Castell, \& Domingo, 2008). PCB 126 was the only one varying significantly between seasons $(p<0.05)$ and displayed maximal values by the end of the spring. A very recent study documented the bioaccumulation of some PCBs in farmed gilthead sea bream reared in different aquaculture farms of the Mediterranean area revealed important differences between inland and in-shore sea farms, suggesting that commercial feed is an important source of PCBs (Pinto et al., 2008). Bell et al. (2005) has already reported that concentrations of dioxins and DL-PCBs in salmon flesh samples were correlated with feed concentrations, but values in flesh were always lower than in feed.

The WHO-TEQ for both PCBs $(0.42 \pm 0.08 \mathrm{pg} / \mathrm{g}$ wet weight $)$ and PCDD/F $(0.10 \pm 0.01 \mathrm{pg} / \mathrm{g}$ wet weight) were far below the maximum levels established by the European Commission (4.0 pg/g wet weight for PCDD/F and $8.0 \mathrm{pg} / \mathrm{g}$ wet weight for PCDD/F-PCB) and hence safe for human consumption. PCDD/PCDF and PCBs concentrations in fish are highly variable, and mainly depend on the fish species and fishing ground. In recent years, although an important number of studies have focused on contaminants in several edible marine species from several areas in Europe (Domingo et al., 2007), gilthead sea bream was poorly analysed. A study with fish samples from the Greek market (which most probably included sea bream, though it is not explicit) reported 0.12 and $0.42 \mathrm{pg}$ TEQ/g ww PCDD/F in wild and cultivated fish, respectively. TEQ non-ortho PCBs ranged between 0.33 and 1.19 for the same group of fish (Papadopoulos, 2004). A survey produced in UK analysed 24 fish species and detected dioxins and PCBs in all samples, total TEQ concentrations ranging from 0.01$3.17 \mathrm{ng}$ WHO-TEQ/kg fresh weight, with higher concentrations generally found in oily fish (Food Standard Agency, 2006). Farmed sea bream and sea bass were also analysed in that survey and registered 0.3 and $1.2 \mathrm{ng}$ WHO-TEQ/kg fresh weight for dioxin and PCBs, respectively. In the present study, values obtained for both dioxins and PCBs in gilthead sea bream (0.1 and $0.42 \mathrm{pg}$ WHO-TEQ/g ww, respectively) did not vary significantly between seasons, or fishing grounds and were very similar to values previously obtained for wild white sea bream from the Spanish coast (Bordajandi et al., 2006). If higher contamination levels were reported for gilthead sea bream from the UK market and also for other edible marine fish species from Adriatic or Mediterranean sea (Bordajandi et al., 2004; Papadopoulos et al., 2004), it must be emphasized a significant decrease of the PCDD/Fs and PCBs in several food items, including fish, during the last few years (Llobet et al., 2008).

The European Commission has recently established maximum allowed levels in the muscle of several fish species ( $\left.\mathrm{N}^{\circ} 629 / 2008\right)$ for $\mathrm{Pb}(0.30 \mathrm{mg} / \mathrm{kg} \mathrm{ww}), \mathrm{Cd}(0.5 \mathrm{mg} / \mathrm{kg} \mathrm{ww}), \mathrm{Hg}(1.0$ $\mathrm{mg} / \mathrm{kg} \mathrm{ww}$ ), but not for As or Ni. The present levels observed in farmed gilthead sea bream were all far below EU limits and hence totally safe for human consumption. Compared to the existing regulation limits for $\mathrm{Cd}, \mathrm{Hg}$ and $\mathrm{Pb}$, levels measured in the edible part of the fish are 6 to 10 times under these values $(\mathrm{Hg}, \mathrm{Pb})$ or under the detection limit $(\mathrm{Cd})$. The present study reported a very low deposition level of $\mathrm{Hg}$ in the muscle of gilthead sea bream, compared to studies with other fish species (Bordajandi et al., 2004). No seasonal variation could be depicted for $\mathrm{As}, \mathrm{Cd}$ and $\mathrm{Hg}$, but $\mathrm{Ni}$ displayed maximal values in October whereas $\mathrm{Pb}$ was more concentrated in June. Results obtained for lead were well within the range of values recently reported for gilthead sea bream that being a semi pelagic fish was shown to be particularly related to water column (Vicente-Martorell, Galindo-Riaño, García-Vargas, \& Granado-Castro, 2009) and were all considerably lower the permissible limits. On the whole, contaminant levels appear to be very low and all samples analysed for both dioxin and dioxin-like PCBs and heavy metals contaminants showed a notably lower concentration than the maximum limit level set by (EC) Regulation $N^{\circ} 1881 / 2006$, modified by $N^{\circ} 629 / 2008$, for human consumption. Therefore, all these samples can be considered as safe with regard to the levels obtained and the in-force legislation.

Fatty acid composition of the edible part a fish is of particular interest for human consumption due to its richness in polyunsaturated fatty acids known to provide numerous health benefits. In a recent review by Grigorakis (2007) the reported mean values for saturated, monounsaturated and n-3 polyunsaturated fatty acids groups in cultured sea bream were 23, 28 and $26 \%$, respectively, being quite close to those of wild specimen. The higher saturated and monounsaturated fatty acid content registered in the present study and the low level of 
n-3 polyunsaturated fatty acids fraction, especially in June are probably a direct effect of fish meal or fish oil replacement by plant proteins or vegetable oils as recently demonstrated on commercial sized gilthead sea bream (Izquierdo, et al., 2005; De Francesco et al. 2007, Fountoulaki et al., 2009). The exact diet formulation used by the different fish farms sampled in this study is unknown, but the incorporation of vegetable sources seems to be a major trend.

Compared to data in literature, levels observed for eicosapentaenoic (C20:5n-3) and docosahexaenoic (C22:6n-3) acids were very low, an average of $1.9 \%$ and $1.8 \%$, respectively. These values are under the common range of variation between 7 and $12 \%$ found in studies using fish oil-based diets (De Francesco et al., 2007; Fountoulaki et al., 2009) and even under the $2 \%$ or $4 \%$ levels observed by Izquierdo el al. (2005), when high rates of fish oil are replaced by plant oil. Our results could be a consequence of such feeding strategy along the rearing step. It is now well established that fatty acid composition in fish flesh reflects the dietary fatty acid profile. Hence, the large variation in some flesh fatty acids, especially in linoleic acid, averaging $13.6 \% \pm 8.2$ over the year, is a possible consequence of different degrees of incorporation of plant sources in the diets selected by the various fish farms. Moreover, the final $n-3 / n-6$ ratio reflects the general nutritional balance of the flesh and shows in most of the samples, a higher level in n-6 polyunsaturated fatty acids. In June 2007, in particular, where very low levels of n-3 polyunsaturated fatty acids were also reported, the general fatty acids profile did not match the nutritional recommendations for French adults (Martin, 2001) that suggest to provide a balance between C18:3n-3 and C18:2n- 6 of 1 to 5 . Moreover, compared to the recommended daily intake of $0.1 \mathrm{~g}$ for DHA and $2 \mathrm{~g}$ for linolenic acid, it can be conclude that for most of sea bream analysed in this study, such nutritional recommendations will not be fulfilled, mainly for C18:3n-3. These results showed that sea bream present a substantial fatty acid variation according to the farm or the season, and the choice of commercial feed formulation is certainly a major determinant of final flesh quality.

Contrarily to fatty acids, the flesh protein content of sea bream within each period, was very similar, and within the same range of values previously reported in different studies (Grigorakis, 2007); it is generally admitted that both farmed and wild fish have essentially the same protein content (Johnsen, 1991). Total amino acids composition remained relatively unchanged within each period. There is a general lack of data regarding muscle amino acids in commercial sized sea bream and the factors affecting them (Grigorakis, 2007), with the exception of a study by Gomez-Requeni et al. (2004) on juveniles gilthead sea bream, and more recently the work of De Francesco et al. (2007) showing an increase of some muscle free amino acids with the fish meal replacement by plant protein sources. Results of this present study show that sea bream reared under intensive conditions in France, Greece or Spain have a rather good balance on essential amino acids and that potential variation on feeding or others rearing factors are not reflected on muscle amino acid profile. The review of Boutry et al. (2008) on essential amino acids requirements showed that recommendation for an adult man weighing $70 \mathrm{~kg}$ is about $12-14 \mathrm{~g}$ per day. Results obtained on sea bream showed that $200 \mathrm{~g}$ of sea bream from intensive production nearly met this daily requirement. In most markets, consumers show a preference for a firm texture such that fibre density can be regarded as a highly desirable quality attribute. The textural characteristics of the flesh are a function of muscle fibres, connective tissue and fat cells (Johnston et al., 2000a). Intraspecific studies on the relationship between muscle cellularity and flesh quality parameters have been reported in several fish species (Periago, 2005; Johnston et al., $2000 \mathrm{~b}$ ), but the seasonal variation of those parameters in gilthead sea bream produced in intensive fish farms has never been evaluated, in spite of its practical importance for aquaculture. Muscle cellularity results showed that total number of white fibres in the dorsal muscle varied significantly among seasons $(p<0.05)$ pointing to an association between fast muscle growth and fibre recruitment. The highest total number of fibres (161600 \pm 23300$)$ and dorsal white muscle area $\left(445.5 \pm 51.7 \mathrm{~mm}^{2}\right)$ in October is the result of a previous period of intensive hyperplastic growth probably induced by both the highest temperatures and feed intake during summer time. Although the number of small fibres $(<25 \mathrm{~mm})$ did not show a 
significant seasonal variation, the highest value was registered in June indicating a period of more intense cell proliferation. Similarly, in distinct Atlantic salmon populations, the crosssectional area of white muscle and the number of white fibres showed seasonal fluctuations. The recruitment of white fibres increased during the summer and was associated to fast growth (Johnston et al., 2000b).

Muscle fibre diameter and white fibres density are important determinant of the textural characteristics of fish flesh (Periago et al., 2005) but in the present study no significant seasonal variation could be observed in farmed gilthead sea bream. Samples collected both in June and October showed very little variation in fibre density, nevertheless, in March, the variation among sampling grounds was very significant (from 24 to 100 fibres $\mathrm{mm}^{2}$ ) and was superior to that observed between seasons. These results are in general accordance with previous observations in halibut where the contribution of fast muscle fibre density to texture was found to vary from not being significant (August and November) to having a larger effect in May (Hagen, Solberg, Sirnes, \& Johnston, 2007). Similarly, there was a significant variation $(p<0.05)$ within seasons concerning white muscle total dorsal cross-sectional area and fibre number. As no correlation could be established between muscle cellularity and body length or fish weight, the observed differences must be due to distinct growth patterns at each fishing ground mainly related to distinct genetic origin or environmental conditions. In several other fish species, muscle cellularity was shown to vary among fish populations or strains (Johnston et al., 2000b) and also have considerable plasticity with respect to abiotic factors, such as diet (Silva et al., 2009), exercise training (Bjornevik, Karlsen, Johnston, \& Kiessling, 2003) and water temperature (Ayala et al., 2001).

Compared to muscle, very little information is available on fish adipose tissue. The total mean cross-sectional area occupied by the subcutaneous adipose tissue varied significantly among seasons $(P<0.05)$. Fish sampled in October displayed significantly higher values than fish sampled either in June or March. Moreover, there was a significant variation $(p<0.05)$ among fishing grounds, within seasons, concerning this parameter which was positively correlated with dorsal white muscle area and muscle lipid content $(p<0.05)$. Previous studies demonstrated that rainbow trout strains with a high growth rate were also characterized by a high rate of adipose tissue deposition (Fauconneau et al., 1997).

From a sensory point of view, even if parameters of texture presented a low range of variation between samples, it is interesting to note that some criteria as density of the flesh, fibrous and sticky texture as well as chewiness had relatively high scores (data not shown) for these products. Fountoulaki et al. (2009) already highlighted these textural characteristics of the reared fish, i.e. high stickiness, hardness and cohesiveness of the fillets and suggested that the low fish meal content could explain these observations. This is in agreement with the recent review of Gatlin et al. (2007) on the effects of protein source use in aquafeeds on product quality, particularly when large substitutions were made, even if other studies failed to confirm this (De Francesco et al., 2007). The measured colour of sea bream samples evaluated in this study did not reflect a great variability but the general appearance of cooked fillets is a white colour with a more or less marked yellow hue. A variation in the colour of trout was previously reported (De Francesco et al., 2004) and authors hypothesized relationships with feed composition and the presence of corn gluten meal or carotenoids. In our study, data supplied on fish feed were too general to allow such an analysis, although data on muscle fatty acid profile strongly suggest the inclusion of vegetable dietary sources.

The simultaneous representation of sensory variables and individual samples for all the periods (Figure 2) allowed a more detailed observation of the within and between seasonal variation. Hence, it is possible to identify a clear seasonal effect on some sensory characteristics. In March 2008 (period 3), there was a general trend to have less fatty characteristics (odour, flavour, fat film on the tongue) and a less white colour, for sea bream. But the seasonal effect is not observed in the case of farms A or B and these findings could suggest that global rearing conditions adopted in some farms could lead to a general "fingerprint" of the fish produced in these farms. 
The main correlations were identified between muscle dry matter and lipid content and the intensity of global flavour, the fat flavour, the fat film perception in mouth and also the presence of fat droplets in the bowl after cooking. All these sensory descriptors increased with muscle lipid content and in a lesser extent with the level of polyunsaturated fatty acids n6 . The level of polyunsaturated fatty acids $n-6$ could be an illustration of the use of vegetable oils in the diet of fish and could have an impact on sensory properties as mentioned by Izquierdo et al. (2005). The good correlation between the lightness of the flesh after cooking expressed by $L^{*}$ value, the lipid content of the muscle and the panel perception for white colour and colour homogeneity confirms previous works showing an increase of the whiteness with fat content in the flesh (Grigorakis, 2007). Moreover, the perception of higher moisture in some samples could be a consequence of higher fat content in the flesh and could be equivalent to the perception of juiciness described as smooth and succulent mouth sensation by Love (1992).

In conclusion, this study has shown that reared sea bream produced in some intensive system farms in France, Greece or Spain presented far lower concentrations for contaminant as dioxin and dioxin-like PCBs or heavy metals than the maximum limit level set by EC Regulation, hence totally safe for human consumption. Among the characteristics measured, a season effect has been mainly observed on lipid level for whole fish and edible flesh, trimmed fraction after filleting procedure, polyunsaturated fatty acids $n-3$ and histological parameters as the total number of white fibres. Sensory evaluation allowed also to point out differences related to fat content, through criteria of fatty odour and flavour or fat film on the tongue. The fat level was generally high for this species and the fluctuations could be attributed to the rearing conditions including, feed formulation and feeding rate but also to water temperature or other rearing conditions. We can hypothesis that the feeding strategy adopted by the farm has a major impact on the nutritional quality of the flesh as shown by the differences in fatty acids groups and especially in polyunsaturated fatty acids n-3 and n-6, observed between periods and fishing grounds. Therefore it can be concluded that intensive farming does not allow to guarantee the consumer constant nutritional values in reared sea bream, from season to season or from farm to farm. These fatty acid fluctuations clearly influenced the sensory properties of the cooked flesh. The increased fat content of the flesh and, in a lesser extend the presence of polyunsaturated fatty acids n-6, lead to more intense odour and flavour with fatty fish characteristics. Moreover, the flesh presented a whiter appearance, with greater colour homogeneity and increased number of fat droplets in gravy after cooking. The range of variation was lower on texture; small differences existed on firmness and moisture difficulting the detection of high relationships with histological parameters. Protein content and amino acid composition were found rather stable whatever the samples. This clearly illustrates their high conservation in fish flesh, even if feed different regimes. Regarding commercial traits, no significant difference has been noticed on the edible part fraction obtained after filleting the different samples.

Although a clear seasonal effect is observed on some quality criteria, the effect of the farms rearing techniques seems to modulate the major characteristics of the fish. These results have been obtained for a European project, SEACASE, which intends to analyse the opportunities of development a sustainable aquaculture preserving the marine resources while reducing its impact on environment; this project focus in particular on extensive and semi intensive aquaculture. The knowledge of the range of variation of different quality characteristics of commercial products reared in intensive system will be therefore useful for further comparisons with fish produced under less intensive systems. 


\section{Acknowledgements}

This research has been carried out with the financial support from the Commission of the European Communities, specific RTD programme "Specific Support to Policies", SSP-200544483 "SEACASE - Sustainable extensive and semi-intensive coastal aquaculture in Southern Europe, and does not necessarily reflect the European Commission views and in no way anticipates the Commission's future policy in this area. The authors are grateful to Fernanda Malhao for her technical support and to the sensory trained panel of IFREMER.

\section{References}

Andrew, J. E., Holm, J. \& Huntingford, F. A., (2004). The effect of pellet texture on the feeding behaviour of gilthead sea bream (Sparus aurata L.). Aquaculture, 232(1-4), 471-479.

Anonymous (1997). Conquering suffering, enriching humanity. In : The world health report. World health organization, Geneva., $162 \mathrm{p}$.

AOAC (Association of Official Analytical Chemistry) (2005). Official methods of analysis of AOAC international. Washington, DC.

Ayala, M.D., Lopez-Albors, O., Gil, F., Garcia-Alcazar, A., Abellan, E., Alarcon, J.A., Alvarez, M.C., Ramirez-Zarzosa, G., \& Moreno, F. (2001). Temperature effects on muscle growth in two populations (atlantic and mediterranean) of sea bass, dicentrarchus labrax I. Aquaculture, 202, 359-370.

Baeyens, W., Leermakers, M., Elskens, M., Van Larebeke, N., De Bont, R., Vanderperren, H., Fontaine, A., Degroodt, J.M., Goeyens, L., Hanot, V., \& Windal, I. (2007). Pcbs and $\mathrm{pcdd} / \mathrm{fs}$ in fish and fish products and their impact on the human body burden in belgium. Archives of Environmental Contamination and Toxicology, 52, 563-571

Bagni, M., Civitareale, C., Priori, A., Ballerini, A., Finoia, M., Brambilla, G., \& Marino, G. (2007). Pre-slaughter crowding stress and killing procedures affecting quality and welfare in sea bass (Dicentrarchus labrax) and sea bream (Sparus aurata). Aquaculture, 263(1-4), 5260.

Bell, J.G., McGhee, F., Dick, J.R., \& Tocher, D.R. (2005). Dioxin and dioxin-like polychlorinated biphenyls (PCBs) in Scottish farmed salmon (Salmo salar): effects of replacement of dietary marine fish oil with vegetable oils. Aquaculture, 243, 305-314.

Bjornevik, M., Karlsen, O., Johnston, I.A., \& Kiessling, A. (2003). Effect of sustained exercise on white muscle structure and flesh quality in farmed cod (gadus morhua I.). Aquaculture Research, 34, 55-64.

Bordajandi, L.R., Gomez, G., Abad, E., Rivera, J., Fernandez-Baston, M.d.M., Blasco, J., \& Gonzalez, M.J. (2004). Survey of Persistent Organochlorine Contaminants (PCBs, PCDD/Fs, and PAHs), Heavy Metals ( $\mathrm{Cu}, \mathrm{Cd}, \mathrm{Zn}, \mathrm{Pb}$, and $\mathrm{Hg}$ ), and Arsenic in Food Samples From Huelva (Spain):\&nbsp; Levels and Health Implications. Journal of Agricultural and Food Chemistry, 52, 992-1001.

Bordajandi, L.R., Martín, I., Abad, E., Rivera, J., \& González, M.J. (2006) Organochlorine compounds (pcbs, pcdds and pcdfs) in seafish and seafood from the spanish atlantic southwest coast. Chemosphere, 64, 1450-1457. 
Boutry, C., Bos, C., \& Tomé, D. (2008) Amino acid requirements. Nutrition clinique et métabolisme, 22, 151-160.

Calabretti, A., Cateni, F., Procida, G., \& Favretto, L. G. (2003). Influence of environmental temperature on composition of lipids in edible flesh of rainbow trout (Oncorhynchus mykiss). Journal of the Science of Food and Agriculture, 83, 1493-1498.

CIE (Commission Internationale de l'Eclairage) (1976). Colorimetry. Publ. $N^{\circ} 15$, Bureau Central de la CIE, Vienna, Austria.

Commission Regulation (EC) No 1881/2006 (2006). Setting maximum levels for certain contaminants in foodstuffs. Official Journal of the European Union, L 364, 5-23.

Commission Regulation (EC) $N^{\circ}$ 629/2008 (2008). Setting maximum levels for certain contaminants in foodstuffs. Official Journal of the European Union, L 173, 6-9.

De Francesco, M., Parisi, G., Médale, F., Lupi, P., Kaushik, J., \& Poli, B. M. (2004). Effect of long-term feeding with a plant protein mixture based diet on growth and body/fillet quality traits of large rainbow trout (Oncorhynchus mykiss). Aquaculture, 236, 413-429.

De Francesco, M., Parisi, G., Perez-Sanchez, J., Gomez-ReQueni, P., Médale, F., Kaushik, S. J., Mecatti, M., \& Poli, B. M. (2007). Effect of high-level fish meal replacement by plant proteins in gilthead sea bream (Sparus aurata) on growth and body/fillet quality traits. Aquaculture Nutrition, 13(5), 361-372.

Domingo, J.L., \& Bocio, A. (2007). Levels of pcdd/pcdfs and pcbs in edible marine species and human intake: A literature review. Environment International, 33, 397-405.

Dordet, Y. (1990). La colorimétrie, Principes et Applications, Eds Eyrolles, 137p.

Eroldogan, O. T., Kumlu, M., \& Aktas, M. (2004). Optimum feeding rates for European sea bass Dicentrarchus labrax L. reared in seawater and freshwater. Aquaculture, 231(1-4), 501515.

FAO (Food and Agricultural Organization) (2008). The state of fisheries and aquaculture, Fisheries and Aquaculture Department, Rome, Electronic Publishing Policy and Support Branch Communication Division

Fauconneau, B., Andre S., Chmaitilly J., Bail P. Y., Krieg F., \& Kaushik S. J. (1997). Control of skeletal muscle fibres and adipose cells size in the flesh of rainbow trout. Journal of Fish Biology, 50, 296-314.

FEAP (Federation of European Aquaculture Producers) (2008). Production and price reports of member associations of the FEAP (2001-2008). Available for download at the FEAP website: http://www.feap.info/production/euproduction/productionreport_en.asp.

Folch, J., Lees, M., \& Sloane-Stanley, G.H. (1957). A simple method for the isolation and purification of total lipids from animal tissues. Journal of biological chemistry, 226, 497-509.

Food Standards Agency. (2006). Dioxines and dioxine-like pcbs in farmed \& wild fish and shelfish. Food Standards Agency.

Fountoulaki, E., Vasilaki, A., Hurtado, R., Grigorakis, K., Karacostas, I., Nengas, I., Rigos, G., Kotzamanis, Y., Venou, B., \& Alexis, M. N. (2009). Fish oil substitution by vegetable oils 
in commercial diets for gilthead sea bream (Sparus aurata L.); effects on growth performance, flesh quality and fillet fatty acid profile: Recovery of fatty acid profiles by a fish oil finishing diet under fluctuating water temperatures. Aquaculture, 289(3-4), 317-326.

Gatlin III, D. M., Barrows, F. T., Brown, P., Dabrowski, K., Gaylord, T. G., Hardy, R. W., Herman, E., Hu, G., Krogdahl, Å., Nelson, R., Overturf, K., Rust, M., Sealey, W., Skonberg, D., Souza, E. J., Stone, D., Wilson, R., \& Wurtele, E. (2007). Expanding the utilization of sustainable plant products in aquafeeds: a review Aquaculure Research, 38(6), 551-579

Gomez-Requeni, P., Mingarro, M., Calduch-Giner, J. A., Médale, F., Martin, S. A. M., Houlihan, D. F., Kaushik, S., \& Perez-Sanchez, J. (2004). Protein growth performance, amino acid utilisation and somatotropic axis responsiveness to fish meal replacement by plant protein sources in gilthead sea bream (Sparus aurata). Aquaculture, 232(1-4), 493-510.

Grigorakis, K. (2007). Compositional and organoleptic quality of farmed and wild gilthead sea bream (Sparus aurata) and sea bass (Dicentrarchus labrax) and factors affecting it: A review. Aquaculture, 272(1-4), 55-75.

Hagen, O., Solberg, C., Sirnes, E., \& Johnston, I.A. (2007). Biochemical and structural factors contributing to seasonal variation in the texture of farmed atlantic halibut (hippoglossus hippoglossus I.) flesh. Journal of Agricultural and Food Chemistry, 55, 58035808.

Hillestad, M. Johnsen, F. Austreng, E., \& Åsgård T. (1998). Long-term effects of dietary fat level and feeding rate on growth, feed utilization and carcass quality of Atlantic salmon. Aquaculture Nutrition, 4(2), 89-97.

ISO, International Organization for Standardization (1988). Sensory analysis - General guidance for the design of test rooms, ISO 8589, Geneva, Switzerland

ISO, International Organization for Standardization (2003). Sensory analysis - Methodology General guidance for establishing a sensory profile, ISO 13299, Geneva, Switzerland

Izquierdo, M.S., Montero, D., Robaina, L., Caballero, M.J., Rosenlund, G., \& Gines, R. (2005). Alterations in fillet fatty acid profile and flesh quality in gilthead sea bream (Sparus aurata) fed vegetable oils for a long term period. Recovery of fatty acid profiles by fish oil feeding. Aquaculture, 250, 431.

Johnsen, P.B. (1991). Aquaculture product quality issues. Journal of Animal Science, 69, 4209-4215.

Johnston, I.A., Alderson, R., Sandham, C., Dingwall, A., Mitchell, D., Selkirk, C., Nickell, D., Baker, R., Robertson, B., Whyte, D., \& Springate, J. (2000a). Muscle fibre density in relation to the colour and texture of smoked atlantic salmon (salmo salar I.). Aquaculture, 189, 335349.

Johnston, I.A., Alderson, R., Sandham, C., Mitchell, D., Selkirk, C., Dingwall, A., Nickell, D., Baker, R., Robertson, B., Whyte, D., \& Springate, J. (2000b). Patterns of muscle growth in early and late maturing populations of atlantic salmon (salmo salar I.). Aquaculture, 189, 307333.

Kestin, S.C., \& Warriss, P.D. (2001). Farmed fish quality. Blackwell Science, Oxford. 
Llobet, J.M., Martí-Cid, R., Castell, V., \& Domingo, J.L. (2008). Significant decreasing trend in human dietary exposure to pcdd/pcdfs and pcbs in catalonia, spain. Toxicology Letters, $178,117-126$.

Love, R.M. (1992) Biochemical dynamics and the quality of fresh and frozen fish. In Fish Processing Technology, Hall, G.M. (Ed.) VHC Pub. Inc., New York, pp. 1-30.

Martin A. coordonnateur (2001). Apports nutritionnels conseillés pour la population française. Tec \& Doc, 3e édition, Paris.

Papadopoulos, A., Vassiliadou, I., Costopoulou, D., Papanicolaou, C., \& Leondiadis, L. (2004). Levels of dioxins and dioxin-like pcbs in food samples on the greek market. Chemosphere, 57, 413-419.

Periago, M. J., Ayala, M. D., Lopez-Albors, O., Abdel, I., Martinez, C., Garcia-Alcazar, A., Ros, G., \& Gil, F. (2005). Muscle cellularity and flesh quality of wild and farmed sea bass, Dicentrarchus labrax L. Aquaculture, 249(1-4), 175-188.

Pinto, B., Garritano, S., Cristofani, R., Ortaggi, G., Giuliano, A., Amodio-Cocchieri, R., Cirillo, T., De Giusti, M., Boccia, A., \& Reali, D.(2008). Monitoring of polychlorinated biphenyl contamination and estrogenic activity in water, commercial feed and farmed seafood. Environmental Monitoring and Assessment, 144, 445-453.

Reis, P. A., \& Almeida, C. M. R. (2008). Matrix importance in animal material pre-treatment for metal determination. Food Chemistry, 107(3), 1294-1299.

Rowlerson, A., Mascarello, F., Radaelli, G., \& Veggetti, A. (1995). Differentiation and growth of muscle in the fish sparus aurata (I): li. Hyperplastic and hypertrophic growth of lateral muscle from hatching to adult. Journal of Muscle Research and Cell Motililty, 16, 223-236.

Shearer, K.D. (1994). Factors affecting the proximate composition of cultured fishes with emphasis on salmonids. Aquaculture, 119, 63-88.

Silva, P., Valente, L.M.P., Galante, M.H., Andrade, C.A.P., Monteiro, R.A.F., \& Rocha, E. (2009). Dietary protein content influences both growth and size distribution of anterior and posterior muscle fibres in juveniles of pagellus bogaraveo (brunnich). Journal of Muscle Research and Cell Motililty, 30, 29-39.

Sveinsdóttir, K., Martinsdóttir, E., Green-Petersen, D., Hyldig, G., Schelvis, R., \& Delahunty, C. (2009). Sensory characteristics of different cod products related to consumer preferences and attitudes. Food Quality and Preference, 20(2), 120-132.

Vicente-Martorell, J.J., Galindo-Riaño, M.D., García-Vargas, M., \& Granado-Castro, M. (2009). Bioavailability of heavy metals monitoring water, sediments and fisg species from polluted estuary. Journal of Hazardous Materials, 162, 823-836.

Zar, J.H. (1999). Biostatistical analysis, London: Prentice Hall. 
Table 1. Body morphological traits and whole composition (on wet weight basis) of sea bream from intensive aquaculture.

\begin{tabular}{|c|c|c|c|c|}
\hline & $\begin{array}{c}\text { All } \\
\text { periods } \\
(n=18)\end{array}$ & $\begin{array}{c}\text { Period 1 } \\
\text { June } 07 \\
(n=6)\end{array}$ & $\begin{array}{c}\text { Period } 2 \\
\text { October } 07 \\
(n=6)\end{array}$ & $\begin{array}{c}\text { Period 3 } \\
\text { March } 08 \\
(n=6)\end{array}$ \\
\hline \multicolumn{5}{|l|}{ Body traits $^{1}$} \\
\hline Weight (g) & $384.0 \pm 45.3$ & $350.1 \pm 14.8^{a}$ & $384.2 \pm 42.5^{\mathrm{ab}}$ & $418.9 \pm 45.9^{b}$ \\
\hline Fork Length (cm) & $26.4 \pm 1.2$ & - & $25.6 \pm 0.9$ & $27.1 \pm 1.0$ \\
\hline Condition factor & $2.2 \pm 0.1$ & - & $2.3 \pm 0.1^{b}$ & $2.1 \pm 0.1^{\mathrm{a}}$ \\
\hline \multicolumn{5}{|l|}{ Body fractions ${ }^{2} \%$} \\
\hline Viscera & $6.0 \pm 1.1$ & $6.5 \pm 1.3$ & $6.2 \pm 1.0$ & $5.5 \pm 0.8$ \\
\hline Head and bones & $36.7 \pm 2.5$ & $36.0 \pm 2.6$ & $36.0 \pm 2.9$ & $38.2 \pm 1.4$ \\
\hline Trimmed fraction & $15.7 \pm 1.0$ & $16.5 \pm 1.0^{b}$ & $15.6 \pm 0.6^{\mathrm{ab}}$ & $15.1 \pm 0.8^{\mathrm{a}}$ \\
\hline Edible part & $41.5 \pm 1.6$ & $41.0 \pm 1.4$ & $42.2 \pm 2.1$ & $41.2 \pm 1.2$ \\
\hline \multicolumn{5}{|c|}{ Whole body composition ${ }^{3} \%$} \\
\hline Dry matter & $36.7 \pm 2.7$ & $37.5 \pm 2.3^{b}$ & $38.0 \pm 2.1^{b}$ & $34.7 \pm 2.6^{a}$ \\
\hline Ash & $3.5 \pm 0.5$ & $3.9 \pm 0.6^{b}$ & $3.1 \pm 0.2^{\mathrm{a}}$ & $3.45 \pm 0.25^{b}$ \\
\hline Crude proteins & $16.5 \pm 0.8$ & $16.9 \pm 0.6^{b}$ & $16.6 \pm 0.6^{\mathrm{ab}}$ & $16.0 \pm 0.9^{a}$ \\
\hline Total lipids & $16.1 \pm 3.2$ & $16.6 \pm 2.8^{\mathrm{b}}$ & $18.2 \pm 2.7^{b}$ & $13.6 \pm 2.7^{\mathrm{a}}$ \\
\hline
\end{tabular}

${ }^{1}$ Values represent mean and standard deviation on 6 samples per period (30 fish per sample)

${ }^{2}$ Values represent mean and standard deviation on 6 samples per period (20 measurements per sample)

${ }^{3}$ Values represent mean and standard deviation on 6 samples per period (each sample analysed was a pool of 3 fish)

In each line, different superscript letters indicates significant differences between sampling periods Multiple comparison test LSD $(p<0.05)$. 
Table 2: Polychlorinated Dibenzeno(p)dioxines (PCDDs), Polychlorinated Dibenzenofurans (PCDFs), dioxin-like PCBs (DL-PCBs) (pg/g wet weight) and heavy metal deposition (mg/Kg wet weight) in muscle of sea bream from intensive aquaculture in Greece, Spain and France.

\begin{tabular}{|c|c|c|c|c|c|c|c|c|c|}
\hline \multirow[b]{2}{*}{ PCDD } & \multicolumn{3}{|c|}{$\begin{array}{l}\text { All periods } \\
\quad(n=12)\end{array}$} & \multicolumn{3}{|c|}{$\begin{array}{c}\text { Period } 1 \\
\text { June } 07 \\
(n=6)\end{array}$} & \multicolumn{3}{|c|}{$\begin{array}{c}\text { Period } 2 \\
\text { October } 07 \\
(n=6)\end{array}$} \\
\hline & & & & & & & & & \\
\hline 2,3,7,8-TetraCDD & $<0.01$ & \pm & 0.01 & 0.01 & \pm & 0.00 & $<0.01$ & \pm & 0.00 \\
\hline 1,2,3,7,8-PentaCDD & 0.02 & \pm & 0.01 & 0.02 & \pm & 0.01 & 0.02 & \pm & 0.01 \\
\hline 1,2,3,7,8,9-HexaCDD & $<0.01$ & \pm & 0.00 & 0.01 & \pm & 0.00 & $<0.01$ & \pm & 0.00 \\
\hline $1,2,3,6,7,8-H e x a C D D$ & 0.01 & \pm & 0.01 & 0.01 & \pm & 0.00 & $<0.02$ & \pm & 0.01 \\
\hline OctaCDD & 0.05 & \pm & 0.02 & 0.06 & \pm & 0.03 & 0.04 & \pm & 0.01 \\
\hline $\begin{array}{l}\text { 1,2,3,4,7,8-HexaCDD } \\
\text { 1,2,3,4,6,7,8- }\end{array}$ & $<0.01$ & \pm & 0.00 & $<0.01$ & \pm & 0.00 & $<0.01$ & \pm & 0.00 \\
\hline HeptaCDD & 0.01 & \pm & 0.01 & 0.02 & \pm & 0.01 & 0.01 & \pm & 0.00 \\
\hline \multicolumn{10}{|l|}{ PCDF } \\
\hline 2,3,7,8-TetraCDF & 0.26 & \pm & 0.10 & 0.23 & \pm & 0.11 & 0.28 & \pm & 0.10 \\
\hline 2,3,4,7,8-PentaCDF & 0.09 & \pm & 0.03 & 0.09 & \pm & 0.03 & 0.09 & \pm & 0.02 \\
\hline $1,2,3,7,8$-PentaCDF & 0.04 & \pm & 0.01 & 0.04 & \pm & 0.01 & 0.04 & \pm & 0.01 \\
\hline $2,3,4,6,7,8-\mathrm{HexaCDF}$ & $<0.01$ & \pm & 0.00 & $<0.01$ & \pm & 0.00 & $<0.01$ & \pm & 0.00 \\
\hline $1,2,3,4,7,8-\mathrm{HexaCDF}$ & $<0.01$ & \pm & 0.00 & $<0.01$ & \pm & 0.00 & $<0.01$ & \pm & 0.00 \\
\hline $1,2,3,6,7,8-\mathrm{HexaCDF}$ & $<0.01$ & \pm & 0.00 & $<0.01$ & \pm & 0.00 & $<0.01$ & \pm & 0.00 \\
\hline $\begin{array}{l}1,2,3,7,8,9-H e x a C D F \\
1,2,3,4,6,7,8-\end{array}$ & $<0.01$ & \pm & 0.01 & $<0.01$ & \pm & 0.00 & $<0.01$ & \pm & 0.00 \\
\hline $\begin{array}{l}\text { HeptaCDF } \\
1,2,3,4,7,8,9\end{array}$ & $<0.01$ & \pm & 0.00 & $<0.01$ & \pm & 0.00 & $<0.01$ & \pm & 0.00 \\
\hline HeptaCDF & $<0.01$ & \pm & 0.00 & $<0.01$ & \pm & 0.00 & $<0.01$ & \pm & 0.00 \\
\hline OctaCDF & $<0.05$ & \pm & 0.01 & $<0.05$ & \pm & 0.02 & $<0.06$ & \pm & 0.00 \\
\hline $\begin{array}{l}\text { WHO-PCDD/F-TEC } \\
\text { Non-ortho DL-PCBs }\end{array}$ & 0.10 & \pm & 0.03 & 0.10 & \pm & 0.03 & 0.11 & \pm & 0.03 \\
\hline PCB IUPAC No 77 & 10.35 & \pm & 4.25 & 10.85 & \pm & 5.96 & 9.85 & \pm & 1.91 \\
\hline PCB IUPAC Nº 81 & 0.80 & \pm & 0.48 & 1.04 & \pm & 0.56 & 0.57 & \pm & 0.22 \\
\hline PCB IUPAC No 126 & 3.13 & \pm & 0.69 & $3.54^{b}$ & \pm & 0.72 & $2.72^{\mathrm{a}}$ & \pm & 0.35 \\
\hline $\begin{array}{l}\text { PCB IUPAC No } 169 \\
\text { Mono-ortho DL- } \\
\text { PCBs }\end{array}$ & 0.47 & \pm & 0.14 & 0.54 & \pm & 0.15 & 0.40 & \pm & 0.09 \\
\hline PCB IUPAC No 105 & 152.12 & \pm & 37.47 & 157.60 & \pm & 35.23 & 146.64 & \pm & 42.13 \\
\hline PCB IUPAC No 114 & 8.61 & \pm & $\begin{array}{l}2.61 \\
114.9\end{array}$ & 9.27 & \pm & 2.63 & 7.95 & \pm & 2.65 \\
\hline PCB IUPAC No 118 & 484.87 & \pm & 5 & 482.67 & \pm & 87.21 & 487.08 & \pm & 146.46 \\
\hline PCB IUPAC No 123 & 7.10 & \pm & 2.35 & 7.22 & \pm & 2.29 & 6.97 & \pm & 2.62 \\
\hline PCB IUPAC No 156 & 47.07 & \pm & 11.38 & 45.63 & \pm & 11.76 & 48.51 & \pm & 11.91 \\
\hline PCB IUPAC No 157 & 13.65 & \pm & 3.99 & 14.08 & \pm & 4.62 & 13.21 & \pm & 3.63 \\
\hline PCB IUPAC No 167 & 31.16 & \pm & 6.84 & 28.94 & \pm & 7.49 & 33.37 & \pm & 5.91 \\
\hline PCB IUPAC No 189 & 5.48 & \pm & 1.29 & 5.53 & \pm & 1.51 & 5.43 & \pm & 1.17 \\
\hline $\begin{array}{l}\text { WHO-DL-PCBS-TEC } \\
\text { Heavy metals }\end{array}$ & 0.42 & \pm & 0.08 & 0.46 & \pm & 0.08 & 0.38 & \pm & 0.05 \\
\hline As & 0.192 & \pm & $\begin{array}{l}0.087 \\
0.000\end{array}$ & 0.171 & \pm & 0.045 & 0.212 & \pm & 0.117 \\
\hline $\mathrm{Cd}$ & $<0.002$ & \pm & 3 & $<0.001$ & \pm & 0.00 & 0.002 & \pm & 0.000 \\
\hline $\mathrm{Hg}$ & $<0.047$ & \pm & 0.016 & $<0.052$ & \pm & 0.015 & $<0.031$ & \pm & 0.000 \\
\hline $\mathrm{Ni}$ & 0.074 & \pm & 0.027 & 0.053 & \pm & $0.011^{\mathrm{a}}$ & 0.095 & \pm & $0.020^{b}$ \\
\hline $\mathrm{Pb}$ & $<0.035$ & \pm & 0.019 & 0.048 & \pm & $0.010^{\mathrm{b}}$ & $<0.014$ & \pm & $0.002^{\mathrm{a}}$ \\
\hline
\end{tabular}


Values represent mean and standard deviation. In each line, superscript letters indicates significant differences between sampling periods $(p<0.05)$ by one-way ANOVA.

Table 3: Protein content (g $100 \mathrm{~g}^{-1}$ of wet weight), total amino acids profile (\% of total amino acids) and amino acid composition ( $g 100 \mathrm{~g}^{-1}$ of wet weight) in flesh of sea bream from intensive aquaculture at three periods of sampling

\begin{tabular}{|c|c|c|c|c|}
\hline & $\begin{array}{l}\text { All periods } \\
\qquad(n=18)\end{array}$ & $\begin{array}{l}\text { Period } 1 \\
\text { June } 07 \\
(n=6)\end{array}$ & $\begin{array}{c}\text { Period } 2 \\
\text { October } 07 \\
(n=6)\end{array}$ & $\begin{array}{l}\text { Period 3 } \\
\text { March } 08 \\
(n=6)\end{array}$ \\
\hline Dry Matter (\% ww ) & $30.0 \pm 2.6$ & $30.1^{\mathrm{ab}} \pm 3.1$ & $32.0^{\mathrm{b}} \pm 1.7$ & $27.9^{\mathrm{a}} \pm 1.6$ \\
\hline Protein (\% ww) & $19.5 \pm 1.3$ & $18.5^{\mathrm{a}} \pm 1.7$ & $20.6^{\mathrm{b}} \pm 0.7$ & $19.5^{\mathrm{a} b} \pm 0.4$ \\
\hline 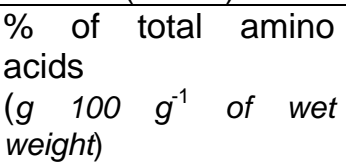 & & & & \\
\hline Isoleucine & $\begin{array}{l}6.9 \pm 0.6 \\
(1.2 \pm 0.3)\end{array}$ & $\begin{array}{l}6.4 \pm 0.2^{\mathrm{a}} \\
\left(0.9 \pm 0.1^{\mathrm{a}}\right)\end{array}$ & $\begin{array}{l}6.6 \pm 0.7^{\mathrm{a}} \\
\left(1.4 \pm 0.4^{\mathrm{b}}\right)\end{array}$ & $\begin{array}{c}7.6 \pm 0.2^{\mathrm{b}} \\
\left(1.2 \pm 0.1^{\mathrm{ab}}\right)\end{array}$ \\
\hline Leucine & $\begin{array}{l}9.4 \pm 0.7 \\
(1.6 \pm 0.3)\end{array}$ & $\begin{array}{c}10.0 \pm 0.8^{\mathrm{b}} \\
\left(1.4 \pm 0.1^{\mathrm{a}}\right)\end{array}$ & $\begin{array}{l}9.2 \pm 0.3^{a} \\
\left(1.9 \pm 0.4^{b}\right)\end{array}$ & $\begin{array}{l}9.0 \pm 0.3^{a} \\
\left(1.4 \pm 0.1^{a}\right)\end{array}$ \\
\hline Lysine & $\begin{array}{l}5.4 \pm 0.5 \\
(0.9 \pm 0.2)\end{array}$ & $\begin{array}{l}5.9 \pm 0.2^{c} \\
\left(0.8 \pm 0.0^{a}\right)\end{array}$ & $\begin{array}{l}5.5 \pm 0.4^{b} \\
\left(1.1 \pm 0.2^{b}\right)\end{array}$ & $\begin{array}{l}4.8 \pm 0.2^{a} \\
\left(0.7 \pm 0.1^{a}\right)\end{array}$ \\
\hline Methionine & $\begin{array}{l}3.6 \pm 0.3 \\
(0.6 \pm 0.1)\end{array}$ & $\begin{array}{l}3.8 \pm 0.4^{\mathrm{a}} \\
\left(0.5 \pm 0.0^{\mathrm{a}}\right)\end{array}$ & $\begin{array}{l}3.5 \pm 0.1^{a b} \\
\left(0.7 \pm 0.2^{b}\right)\end{array}$ & $\begin{array}{l}3.4 \pm 0.1^{b} \\
\left(0.5 \pm 0 . .5^{a}\right)\end{array}$ \\
\hline Phenylalanine & $\begin{array}{l}4.9 \pm 0.3 \\
(0.8 \pm 0.2)\end{array}$ & $\begin{array}{r}5.1 \pm 0.5 \\
\left(0.7 \pm 0.1^{\mathrm{a}}\right)\end{array}$ & $\begin{array}{r}4.9 \pm 0.1 \\
\left(1.0 \pm 0.2^{b}\right)\end{array}$ & $\begin{array}{r}4.8 \pm 0.2 \\
\left(0.7 \pm 0.1^{\mathrm{a}}\right)\end{array}$ \\
\hline Threonine & $\begin{array}{l}5.9 \pm 0.3 \\
(1.0 \pm 0.2)\end{array}$ & $\begin{array}{r}6.1 \pm 0.2^{b} \\
\left(0.9 \pm 0.05^{a}\right)\end{array}$ & $\begin{array}{l}5.8 \pm 0.2^{a b} \\
\left(1.2 \pm 0.3^{b}\right)\end{array}$ & $\begin{array}{l}5.7 \pm 0.2^{\mathrm{a}} \\
\left(0.9 \pm 0.1^{\mathrm{a}}\right)\end{array}$ \\
\hline Valine & $\begin{array}{l}6.5 \pm 0.2 \\
(1.1 \pm 0.2)\end{array}$ & $\begin{array}{c}6.5 \pm 0.1^{a b} \\
\left(0.9 \pm 0.1^{a}\right)\end{array}$ & $\begin{array}{r}6.4 \pm 0.1^{\mathrm{a}} \\
\left(1.3 \pm 0.3^{\mathrm{b}}\right)\end{array}$ & $\begin{array}{c}6.6 \pm 0.2^{b} \\
\left(1.0 \pm 0.1^{a}\right)\end{array}$ \\
\hline EAA & $\begin{array}{c}\mathbf{4 2 . 5} \\
7.2 \pm 1.5\end{array}$ & $\begin{array}{c}43.8^{b^{2}} \\
6.3 \pm 0.3^{a}\end{array}$ & $\begin{array}{c}41.9^{\mathrm{a}} \\
8.7 \pm 1.9^{b}\end{array}$ & $\begin{array}{c}41.8^{\mathrm{a}} \\
6.5 \pm 0.6^{\mathrm{a}}\end{array}$ \\
\hline Alanine & $\begin{array}{c}7.5 \pm 0.4 \\
(1.3 \pm 0.25)\end{array}$ & $\begin{array}{c}7.9 \pm 0.5^{\mathrm{b}} \\
\left(1.1 \pm 0.1^{\mathrm{a}}\right)\end{array}$ & $\begin{array}{l}7.3 \pm 0.2^{\mathrm{a}} \\
\left(1.5 \pm 0.3^{\mathrm{b}}\right)\end{array}$ & $\begin{array}{c}7.2 \pm 0.1^{\mathrm{a}} \\
\left(1.1 \pm 0.1^{\mathrm{a}}\right)\end{array}$ \\
\hline Aspartic acid & $\begin{array}{l}12.3 \pm 1.3 \\
(2.1 \pm 0.6)\end{array}$ & $\begin{array}{l}11.3 \pm 1.4^{\mathrm{a}} \\
\left(1.6 \pm 0.2^{\mathrm{a}}\right)\end{array}$ & $\begin{array}{l}12.7 \pm 0.5^{b} \\
\left(2.6 \pm 0.6^{c}\right)\end{array}$ & $\begin{array}{l}13.7 \pm 0.4^{b} \\
\left(2.1 \pm 0.25^{b}\right)\end{array}$ \\
\hline Glutamic acid & $\begin{array}{c}15.0 \pm 1.4 \\
(2.5 \pm 0.6)\end{array}$ & $\begin{array}{c}14.6 \pm 1.9^{a} \\
\left(2.11 \pm 0.3^{\mathrm{a}}\right)\end{array}$ & $\begin{array}{l}15.3 \pm 1.5^{\prime} \\
\left(3.1 \pm 0.5^{\mathrm{b}}\right)\end{array}$ & $\begin{array}{r}15.1 \pm 0.6 \\
\left(2.3 \pm 0.3^{\mathrm{a}}\right)\end{array}$ \\
\hline Glycine & $\begin{array}{r}6.9 \pm 0.6 \\
(1.2 \pm 0.3)\end{array}$ & $\begin{array}{c}6.8 \pm 0.5 \\
\left(1.0 \pm 0.06^{\mathrm{a}}\right)\end{array}$ & $\begin{array}{c}7.1 \pm 0.8 \\
\left(1.5 \pm 0.3^{b}\right)\end{array}$ & $\begin{array}{c}6.9 \pm 0.4 \\
\left(1.1 \pm 0.9^{\mathrm{a}}\right)\end{array}$ \\
\hline Histidine & $\begin{array}{c}2.7 \pm 0.2 \\
(0.5 \pm 0.1)\end{array}$ & $\begin{array}{c}2.8 \pm 0.2 \\
\left(0.4 \pm 0.0^{\mathrm{a}}\right)\end{array}$ & $\begin{array}{c}2.8 \pm 0.2 \\
\left(0.6 \pm 0.1^{\mathrm{b}}\right)\end{array}$ & $\begin{array}{c}2.6 \pm 0.1 \\
\left(0.4 \pm 0.0^{\mathrm{a}}\right)\end{array}$ \\
\hline Proline & $\begin{array}{c}4.7 \pm 0.4 \\
(0.8 \pm 0.2)\end{array}$ & $\begin{array}{c}4.4 \pm 0.1^{\mathrm{a}} \\
\left(0.6 \pm 0.0^{\mathrm{a}}\right)\end{array}$ & $\begin{array}{c}4.8 \pm 0.3^{b} \\
\left(1.0 \pm 0.2^{b}\right)\end{array}$ & $\begin{array}{c}4.9 \pm 0.4^{\mathrm{b}} \\
\left(0.8 \pm 0.0^{\mathrm{a}}\right)\end{array}$ \\
\hline Serine & $\begin{array}{c}4.7 \pm 0.3 \\
(0.8 \pm 0.2)\end{array}$ & $\begin{array}{c}4.9 \pm 0.1^{b} \\
\left(0.7 \pm 0.0^{\mathrm{a}}\right)\end{array}$ & $\begin{array}{c}4.6 \pm 0.3^{a b} \\
\left(1.0 \pm 0.2^{b}\right)\end{array}$ & $\begin{array}{c}4.4 \pm 0.3^{a} \\
\left(0.7 \pm 0.1^{a}\right)\end{array}$ \\
\hline Tyrosine & $\begin{array}{l}2.8 \pm 0.3 \\
(0.5 \pm 0.1)\end{array}$ & $\begin{array}{c}3.1 \pm 0.2^{b} \\
\left(0.4 \pm 0.0^{a}\right)\end{array}$ & $\begin{array}{l}2.8 \pm 0.2^{\mathrm{ab}} \\
\left(0.6 \pm 0.1^{\mathrm{b}}\right)\end{array}$ & $\begin{array}{c}2.6 \pm 0.3^{a} \\
\left(0.4 \pm 0.1^{a}\right)\end{array}$ \\
\hline Cystine & $\begin{array}{r}0.6 \pm 0.2 \\
(0.1 \pm 0.0)\end{array}$ & $\begin{array}{c}0.5 \pm 0.1 \\
\left(0.1 \pm 0.0^{a}\right)\end{array}$ & $\begin{array}{r}0.6 \pm 0.2 \\
\left(0.1 \pm 0.0^{b}\right)\end{array}$ & $\begin{array}{c}0.8 \pm 0.2 \\
\left(0.1 \pm 0.0^{\mathrm{b}}\right)\end{array}$ \\
\hline NEAA & $\begin{array}{c}\mathbf{5 7 . 5} \\
9.7 \pm 2.2\end{array}$ & $\begin{array}{c}\mathbf{5 6 . 2} \\
8.1 \pm 0.6^{\mathrm{a}}\end{array}$ & $\begin{array}{c}\mathbf{5 8 . 1}^{\mathrm{b}^{-}} \\
12.0 \pm 2.3^{\mathrm{b}}\end{array}$ & $\begin{array}{c}\mathbf{5 8 . 2} \\
9.1 \pm 0.9^{a}\end{array}$ \\
\hline EAA / NEAA & 0.7 & 0.8 & 0.7 & 0.7 \\
\hline
\end{tabular}


Tryptophan and Arginine are not analysed by the method

Values represent mean and standard deviation. In each line, superscript letters indicates significant differences between sampling periods $(p<0.05)$ by one-way ANOVA and Multiple comparison test $\operatorname{LSD}(p<0.05)$.

Table 4 - Total lipid content (g $100 \mathrm{~g}^{-1}$ of wet weight), fatty acids profile (\% of total fatty acids) and fatty acid composition ( $\mathrm{g} 100 \mathrm{~g}^{-1}$ of wet weight) in flesh of sea bream from intensive aquaculture at three periods of sampling

\begin{tabular}{|c|c|c|c|c|}
\hline & $\begin{array}{c}\text { All periods } \\
(n=18)\end{array}$ & $\begin{array}{l}\text { Period 1 } \\
\text { June } 07 \\
(n=6)\end{array}$ & $\begin{array}{c}\text { Period 2 } \\
\text { October } 07 \\
(n=6)\end{array}$ & $\begin{array}{c}\text { Period } 3 \\
\text { March } 08 \\
(n=6)\end{array}$ \\
\hline $\begin{array}{l}\text { Total lipid content } \\
(\% \text { w w) }\end{array}$ & $9.9 \pm 2.7$ & $9.8^{\mathrm{ab}} \pm 2.8$ & $11.9^{b} \pm 2.4$ & $8.1^{a} \pm 2.1$ \\
\hline \multicolumn{5}{|l|}{$\begin{array}{l}\text { \% of total fatty acids } \\
\begin{array}{llll}(g \quad 100 & g^{-1} & \text { of } & \text { wet } \\
\text { weight }\end{array}\end{array}$} \\
\hline C14:0 & $\begin{array}{l}7.8 \pm 3.4 \\
(0.4 \pm 0.3)\end{array}$ & $\begin{array}{l}7.2 \pm 3.6 \\
\left(0.4 \pm 0.2^{a}\right)\end{array}$ & $\begin{array}{c}9.8 \pm 3.9 \\
\left(0.7 \pm 0.3^{b}\right)\end{array}$ & $\begin{array}{l}6.3 \pm 1.7 \\
\left(0.3 \pm 0.1^{\mathrm{a}}\right)\end{array}$ \\
\hline C16:0 & $\begin{array}{l}28.1 \pm 7.6 \\
(1.6 \pm 0.7)\end{array}$ & $\begin{array}{c}28.7 \pm 8.0 \\
\left(1.5 \pm 0.4^{\mathrm{ab}}\right)\end{array}$ & $\begin{array}{l}31.6 \pm 8.8 \\
\left(2.1 \pm 0.8^{\mathrm{b}}\right)\end{array}$ & $\begin{array}{c}24.0 \pm 4.3 \\
\left(1.1 \pm 0.4^{\mathrm{a}}\right)\end{array}$ \\
\hline C16:1n-7 & $\begin{array}{l}8.3 \pm 2.6 \\
(0.5 \pm 0.2)\end{array}$ & $\begin{array}{c}8.9 \pm 4.2 \\
\left(0.5 \pm 0.1^{\mathrm{ab}}\right)\end{array}$ & $\begin{array}{l}8.6 \pm 1.4 \\
\left(0.6 \pm 0.1^{b}\right)\end{array}$ & $\begin{array}{l}7.3 \pm 1.5 \\
\left(0.3 \pm 0.1^{\mathrm{a}}\right)\end{array}$ \\
\hline C18:0 & $\begin{array}{l}4.8 \pm 1.3 \\
(0.3 \pm 0.1)\end{array}$ & $\begin{array}{c}4.6 \pm .6^{\mathrm{ab}} \\
\left(0.2 \pm 0.1^{\mathrm{a}}\right)\end{array}$ & $\begin{array}{l}5.8 \pm 1.3^{b} \\
\left(0.4 \pm 0.1^{b}\right)\end{array}$ & $\begin{array}{l}4.1 \pm 1.3^{a} \\
\left(0.2 \pm 0.1^{\mathrm{a}}\right)\end{array}$ \\
\hline C18:1n-7 & $\begin{array}{l}4.1 \pm 0.7 \\
(0.2 \pm 0.1)\end{array}$ & $\begin{array}{c}4.4 \pm 0.6^{b} \\
\left(0.2 \pm 0.1^{b}\right)\end{array}$ & $\begin{array}{l}4.5 \pm 0.6^{b} \\
\left(0.3 \pm 0.1^{b}\right)\end{array}$ & $\begin{array}{c}3.5 \pm 0.6^{a} \\
\left(0.2 \pm 0.1^{a}\right)\end{array}$ \\
\hline C18:1n-9 & $\begin{array}{l}25.0 \pm 5.2 \\
(1.4 \pm 0.5)\end{array}$ & $\begin{array}{c}27.6 \pm 4.4 \\
(1.6 \pm 0.6)\end{array}$ & $\begin{array}{l}21.8 \pm 6.2 \\
(1.5 \pm 0.5)\end{array}$ & $\begin{array}{l}25.6 \pm 3.5 \\
(1.2 \pm 0.5)\end{array}$ \\
\hline C18:2n-6 & $\begin{array}{l}13.6 \pm 8.2 \\
(0.8 \pm 0.5)\end{array}$ & $\begin{array}{c}16.6 \pm 10.4 \\
(1.0 \pm 0.7)\end{array}$ & $\begin{array}{l}9.3 \pm 5.9 \\
(0.6 \pm 0.5)\end{array}$ & $\begin{array}{l}14.8 \pm 7.0 \\
(0.6 \pm 0.3)\end{array}$ \\
\hline C18:3n-3 & $\begin{array}{c}0.5 \pm 0.9 \\
(0.02 \pm 0.0)\end{array}$ & $\begin{array}{l}\mathrm{Nd} \\
\mathrm{Nd}\end{array}$ & $\begin{array}{l}\mathrm{Nd} \\
\mathrm{Nd}\end{array}$ & $\begin{array}{l}1.6 \pm 0.8 \\
(0.1 \pm 0.0)\end{array}$ \\
\hline C20:1n-9 & $\begin{array}{l}2.8 \pm 1.6 \\
(0.2 \pm 0.1)\end{array}$ & $\begin{array}{l}1.2 \pm 1.2^{\mathrm{a}} \\
\left(0.1 \pm 0.1^{\mathrm{a}}\right)\end{array}$ & $\begin{array}{l}3.9 \pm 1.6^{b} \\
\left(0.3 \pm 0.1^{b}\right)\end{array}$ & $\begin{array}{l}3.4 \pm 0.5^{b} \\
\left(0.1 \pm 0.0^{\mathrm{a}}\right)\end{array}$ \\
\hline C20:5n-3 & $\begin{array}{l}1.9 \pm 1.4 \\
(0.1 \pm 0.1)\end{array}$ & $\begin{array}{l}0.6 \pm 0.4^{a} \\
\left(0.0 \pm 0.0^{\mathrm{a}}\right)\end{array}$ & $\begin{array}{l}2.8 \pm 1.5^{b} \\
\left(0.2 \pm 0.1^{b}\right)\end{array}$ & $\begin{array}{c}2.5 \pm 1.1^{\mathrm{b}} \\
\left(0.1 \pm 0.1^{\mathrm{ab}}\right)\end{array}$ \\
\hline C22:1n-9 & $\begin{array}{c}0.7 \pm 1.1 \\
(0.0 \pm 0.0)\end{array}$ & $\begin{array}{l}\mathrm{Nd} \\
\mathrm{Nd}\end{array}$ & $\begin{array}{l}\mathrm{Nd} \\
\mathrm{Nd}\end{array}$ & $\begin{array}{l}2.2 \pm 0.5 \\
(0.1 \pm 0.0)\end{array}$ \\
\hline$C 22: 5 n-3$ & $\begin{array}{c}0.4 \pm 0.7 \\
(0.0 \pm 0.0)\end{array}$ & $\begin{array}{l}\mathrm{Nd} \\
\mathrm{Nd}\end{array}$ & $\begin{array}{l}\mathrm{Nd} \\
\mathrm{Nd}\end{array}$ & $\begin{array}{l}1.3 \pm 0.6 \\
(0.1 \pm 0.0)\end{array}$ \\
\hline$C 22: 6 n-3$ & $\begin{array}{l}1.8 \pm 1.8 \\
(0.1 \pm 0.1) \\
\end{array}$ & $\begin{array}{l}0.2 \pm 0.3^{a} \\
\left(0.0 \pm 0.0^{a}\right)\end{array}$ & $\begin{array}{l}1.9 \pm 1.1^{b} \\
\left(0.1 \pm 0.1^{b}\right)\end{array}$ & $\begin{array}{l}3.2 \pm 2.0^{\mathrm{b}} \\
\left(0.1 \pm 0.1^{\mathrm{b}}\right)\end{array}$ \\
\hline$\sum$ saturated & $\begin{array}{l}40.7 \pm 11.8 \\
(2.3 \pm 1.0)\end{array}$ & $\begin{array}{l}40.5 \pm 11.6 \\
\left(2.2 \pm 0.5^{\mathrm{ab}}\right)\end{array}$ & $\begin{array}{c}47.2 \pm 13.9 \\
\left(3.2 \pm 1.2^{\mathrm{b}}\right)\end{array}$ & $\begin{array}{l}34.4 \pm 7.2 \\
\left(1.6 \pm 0.6^{a}\right)\end{array}$ \\
\hline$\sum$ monounsaturated & $\begin{array}{c}40.9 \pm 4.9 \\
(2.3 \pm 0.7)\end{array}$ & $\begin{array}{c}42.0 \pm 2.1 \\
(2.4 \pm 0.7)\end{array}$ & $\begin{array}{c}38.8 \pm 7.2 \\
(2.6 \pm 0.7)\end{array}$ & $\begin{array}{c}41.9 \pm 4.0 \\
(2.0 \pm 0.6)\end{array}$ \\
\hline$\sum$ polyunsaturated & $\begin{array}{l}18.3 \pm 9.9 \\
(1.0 \pm 0.5)\end{array}$ & $\begin{array}{c}17.5 \pm 10.7 \\
(1.1 \pm 0.7)\end{array}$ & $\begin{array}{c}14.0 \pm 7.3 \\
(0.9 \pm 0.6)\end{array}$ & $\begin{array}{l}23.4 \pm 10.5 \\
(1.0 \pm 0.4)\end{array}$ \\
\hline$\sum n-3$ & $\begin{array}{l}4.7 \pm 4.2 \\
(0.2 \pm 0.2)\end{array}$ & $\begin{array}{l}0.9 \pm 0.5^{\mathrm{a}} \\
\left(0.0 \pm 0.0^{\mathrm{a}}\right)\end{array}$ & $\begin{array}{l}4.7 \pm 2.5^{\mathrm{b}} \\
\left(0.3 \pm 0.1^{\mathrm{b}}\right)\end{array}$ & $\begin{array}{l}8.6 \pm 4.3^{c} \\
\left(0.4 \pm 0.2^{b}\right)\end{array}$ \\
\hline$\sum n-6$ & $\begin{array}{l}13.6 \pm 8.2 \\
(0.8 \pm 0.5)\end{array}$ & $\begin{array}{l}16.6 \pm 10.4 \\
(1.0 \pm 0.7)\end{array}$ & $\begin{array}{l}9.3 \pm 5.9 \\
(0.6 \pm 0.5)\end{array}$ & $\begin{array}{r}14.8 \pm 7.0 \\
(0.6 \pm 0.2)\end{array}$ \\
\hline Ratio $\sum n-3 / \sum n-6$ & $0.4 \pm 0.3$ & $0.1 \pm 0.0^{\mathrm{a}}$ & $0.5 \pm 0.4^{b}$ & $0.6 \pm 0.3^{b}$ \\
\hline
\end{tabular}

Values represent mean and standard deviation.

$\mathrm{Nd}$ : not detected 
In each line, superscript letters indicates significant differences between sampling periods $(p<0.05)$ by one-way ANOVA and Multiple comparison test LSD.

Table 5. Analysis of white muscle cellularity and colour parameters $\left(L^{*}, a^{\star}, b^{\star}\right)$ on raw and cooked flesh of intensive aquaculture sea bream from Southern Europe.

\begin{tabular}{|c|c|c|c|c|}
\hline & $\begin{array}{c}\text { All periods } \\
(n=18)\end{array}$ & $\begin{array}{c}\text { Period } 1 \\
\text { June } 07 \\
(n=6)\end{array}$ & $\begin{array}{c}\text { Period } 2 \\
\text { October } 07 \\
(n=6)\end{array}$ & $\begin{array}{c}\text { Period } 3 \\
\text { March } 08 \\
(n=6)\end{array}$ \\
\hline \multicolumn{5}{|l|}{ Morphometry } \\
\hline Dorsal Total Section Area $\left(\mathrm{mm}^{2}\right)$ & $510.9 \pm 102.1$ & $439.3 \pm 64.1^{\mathrm{a}}$ & $605.1 \pm 86.9^{b}$ & $\begin{array}{l}488.25 \\
79.65^{a}\end{array}$ \\
\hline $\begin{array}{l}\text { Subcutaneous adipose tissue } \\
\text { area }\left(\mathrm{mm}^{2}\right)\end{array}$ & $38.9 \pm 13.85$ & $33.6 \pm 7.8^{\mathrm{a}}$ & $52.8 \pm 14.3^{b}$ & $30.4 \pm 6.35^{\mathrm{a}}$ \\
\hline \multicolumn{5}{|l|}{ White muscle } \\
\hline Dorsal Area $\left(\mathrm{mm}^{2}\right)$ & $385.1 \pm 66.5$ & $344.9 \pm 42.4^{\mathrm{a}}$ & $445.5 \pm 51.7^{b}$ & $364.9 \pm 52.65^{\mathrm{a}}$ \\
\hline Total fiber number x 1000 & $146.1 \pm 23.35$ & $129.3 \pm 18.5^{\mathrm{a}}$ & $161.6 \pm 23.3^{b}$ & $147.4 \pm 28.2^{\mathrm{ab}}$ \\
\hline Diameter of fibers $(\mu \mathrm{m})$ & $59.1 \pm 3.6$ & $60.2 \pm 3.4$ & $59.7 \pm 2.8$ & $57.5 \pm 4.4$ \\
\hline $\mathrm{N}^{0}$ fibers $/ \mathrm{mm}^{2}$ & $384.2 \pm 56.45$ & $373.6 \pm 31.9$ & $370.15 \pm 53.4$ & $408.8 \pm 82.65$ \\
\hline$\%$ fibers $<25 \mu \mathrm{m}$ & $8.4 \pm 3.3$ & $8.85 \pm 3.6$ & $7.8 \pm 0.9$ & $8.5 \pm 4.8$ \\
\hline \multicolumn{5}{|l|}{ Colour parameters } \\
\hline \multicolumn{5}{|l|}{ Raw fillets } \\
\hline$L^{*}$ & $42.3 \pm 2.3$ & $42.6 \pm 3.2$ & $43.1 \pm 1.3$ & $41.25 \pm 2.3$ \\
\hline$a^{*}$ & $-0.9 \pm 0.6$ & $-0.6 \pm 0.2^{b}$ & $-0.5 \pm 0.3^{b}$ & $-1.5 \pm 0.5^{a}$ \\
\hline$b^{*}$ & $-0.2 \pm 1.6$ & $-0.4 \pm 2.1$ & $-0.04 \pm 0.1$ & $-0.1 \pm 2.0$ \\
\hline \multicolumn{5}{|l|}{ Cooked fillets } \\
\hline$L^{*}$ & $79.2 \pm 2.0$ & $80.8 \pm 1.1^{b}$ & $79.6 \pm 1.6^{b}$ & $77.2 \pm 1.4^{\mathrm{a}}$ \\
\hline$a^{*}$ & $-2.6 \pm 0.55$ & $-2.4 \pm 0.5$ & $-2.85 \pm 0.6$ & $-2.6 \pm 0.45$ \\
\hline$b^{*}$ & $10.6 \pm 1.53$ & $9.6 \pm 1.7$ & $10.6 \pm 1.3$ & $11.5 \pm 1.2$ \\
\hline
\end{tabular}

Values represent mean and standard deviation. In each line. superscript letters indicates significant differences between sampling periods $(p<0.05)$ by one-way ANOVA and Multiple comparison test LSD. 
Figure 1. Sampling organisation for analysis

\begin{tabular}{|c|c|c|c|c|}
\hline & Country & $\begin{array}{l}\text { Period } 1 \\
\text { June } \\
2007\end{array}$ & $\begin{array}{l}\text { Period } 2 \\
\text { October } \\
2007\end{array}$ & $\begin{array}{l}\text { Period } 3 \\
\text { March } \\
2008\end{array}$ \\
\hline \multirow{3}{*}{ Farm origin ${ }^{1,2}$} & France & $\mathrm{A} 1, \mathrm{~B} 1$ & $A 2, B 2$ & A3, B3 \\
\hline & Greece & $\mathrm{C} 1, \mathrm{D} 1, \mathrm{E} 1, \mathrm{F1}$ & $\mathrm{E} 2^{*}, \mathrm{~J} 2, \mathrm{~L} 2$ & $\mathrm{~F}^{*}, \mathrm{~N} 3, \mathrm{~N}^{*}, \mathrm{O} 3$ \\
\hline & Spain & & $\mathrm{H} 2$ & \\
\hline
\end{tabular}

30 fish

\begin{tabular}{|c|c|c|c|c|c|}
\hline 3 fish & 3 fish & 4 fish & \multicolumn{3}{|c|}{20 fish } \\
\hline & & & \multicolumn{3}{|c|}{ Gutting, filleting and trimming yield } \\
\hline$\downarrow$ & $\downarrow$ & 1 & 3 fish & 12 fish & 5 fish \\
\hline $\begin{array}{l}\text { Whole Body } \\
\text { composition }\end{array}$ & $\begin{array}{l}\text { Histology } \\
\text { on } 3 \text { slices }\end{array}$ & $\begin{array}{l}\text { Contaminant } \\
\text { on flesh }\end{array}$ & $\begin{array}{c}\text { Flesh } \\
\text { composition }\end{array}$ & $\begin{array}{c}\text { Sensory } \\
\text { analysis on } \\
\text { cooked fillet }\end{array}$ & $\begin{array}{c}\text { Colour on raw } \\
\text { and cooked } \\
\text { fillet }\end{array}$ \\
\hline$\downarrow$ & $\downarrow$ & $\downarrow$ & $\downarrow$ & & \\
\hline $\begin{array}{l}\text { Dry matter, } \\
\text { lipid, } \\
\text { protein, ash }\end{array}$ & $\begin{array}{l}\text { Number, density } \\
\text { of dorsal white } \\
\text { muscle fibres }\end{array}$ & $\begin{array}{c}\mathrm{PCDD} / \mathrm{F} \\
\mathrm{PCB} \\
\text { heavy metal }\end{array}$ & $\begin{array}{c}\text { Dry matter, } \\
\text { lipid, fatty acid, } \\
\text { protein, amino } \\
\text { acid }\end{array}$ & & \\
\hline
\end{tabular}


Figure 2. Simultaneous projection of variables and products in the plane 1-2 of the principal component analysis on sensory descriptors.

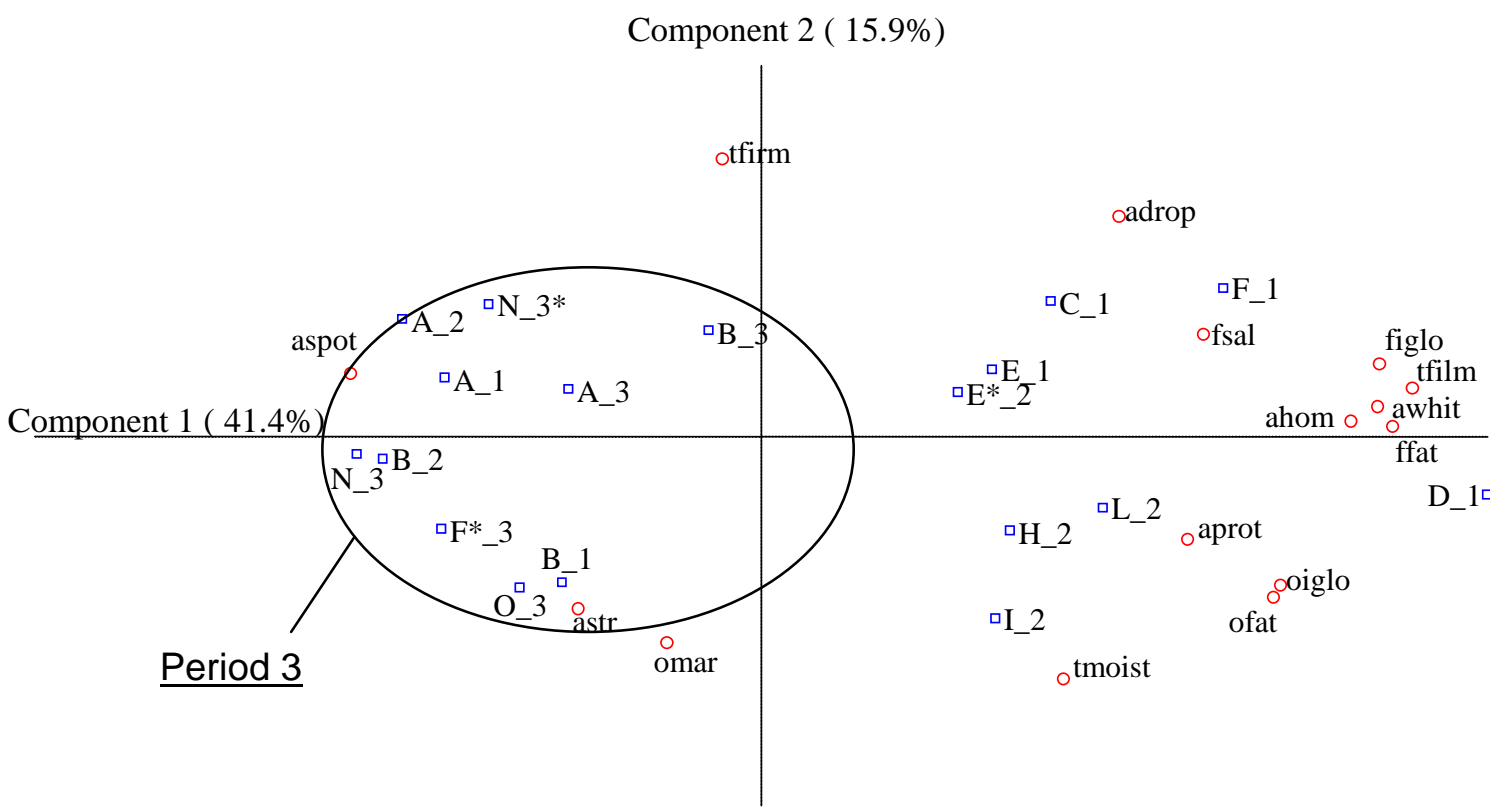

Figure 3. Correlation between chemical. physical and histological criteria and components 1 and 2 of the principal component analysis on sensory descriptors 


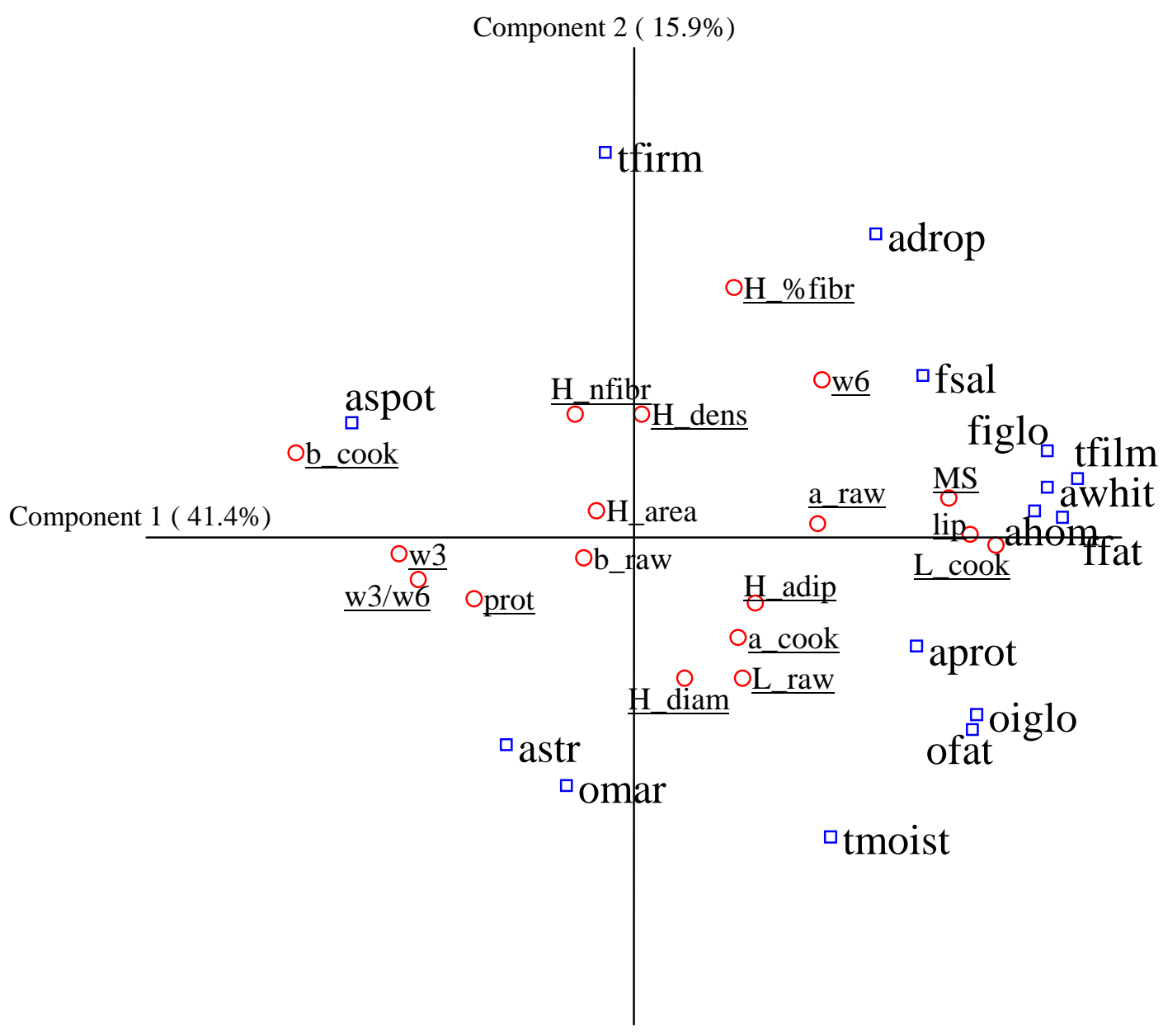

Sensory descriptors: odour, global intensity (oiglo), fat fish (ofat), marine-iodin like (omar); appearance, colour homogeneity (ahom), white colour (awhit), coagulated proteins (aprot), brown spots (aspot), black stria(astr), fat droplets in gravy (adrop); texture, firmness (tfirm), moisture (tmoist), fat film (tfilm); flavour. global intensity (figlo), fat fish (ffat), salty taste (fsal). Chemical measurements : dry matter (MS), lipid content of the flesh (lip), protein content (prot), polyunsaturated fatty acids $n-3$ (n-3), polyunsaturated fatty acids $n-6(n-6)$, ratio $n-3 / n-6$

Colour measurements in $L^{*}, a^{*}, b^{*}$ system: on raw fillet ( $L$ raw, a_raw, b_raw) on cooked fillet (L_cook, a_cook, b_cook). Histological measurements: Dorsal adipose tissue ${ }^{-}$area $\left(\mathrm{mm}^{2}\right)$ (H_adip), dorsal white muscle area ( $\mathrm{H} \_$area), total number of white fibres $\times 1000\left(\mathrm{H} \_n b f i b r\right)$, white fibre diameter $(\mu \mathrm{m})\left(\mathrm{H} \_\right.$diam $)$, number of white fibres/ $\mathrm{mm}^{2}$ (H_dens), \% fibres $<25 \mu \mathrm{m}\left(\overline{\mathrm{H}} \_\% \mathrm{fibr}\right)$

Chemical, physical and histological parameters are underlined. 